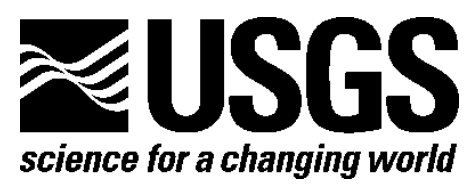

\title{
An Exploration in Mineral Supply Chain Mapping Using Tantalum as an Example
}

By Yadira Soto-Viruet, W. David Menzie, John F. Papp, and Thomas R. Yager

Open-File Report 2013-1239

U.S. Department of the Interior

U.S. Geological Survey 


\section{U.S. Department of the Interior \\ SALLY JEWELL, Secretary}

\section{U.S. Geological Survey \\ Suzette M. Kimball, Acting Director}

U.S. Geological Survey, Reston, Virginia: 2013

For more information on the USGS—-the Federal source for science about the Earth, its natural and living resources, natural hazards, and the environment-visit

http://www.usgs.gov or call 1-888-ASK-USGS

For an overview of USGS information products, including maps, imagery, and publications, visit http://www.usgs.gov/pubprod

To order this and other USGS information products, visit http://store.usgs.gov

Suggested citation:

Soto-Viruet, Yadira, Menzie, W.D., Papp, J.F., and Yager, T.R., 2013, An exploration in mineral supply chain mapping using tantalum as an example: U.S. Geological Survey Open-File Report 2013-1239, 51 p., http://pubs.usgs.gov/of/2013/1239/.

Any use of trade, firm, or product names is for descriptive purposes only and does not imply endorsement by the U.S. Government.

Although this information product, for the most part, is in the public domain, it also may contain copyrighted materials as noted in the text. Permission to reproduce copyrighted items must be secured from the copyright owner.Contents. Contents. 


\section{Contents}

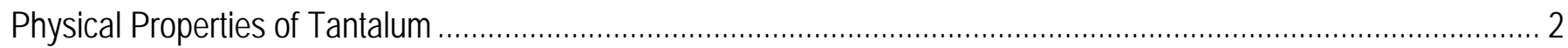

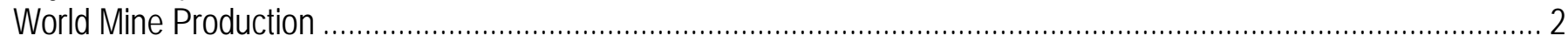

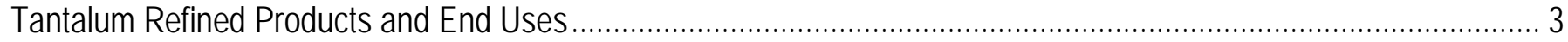

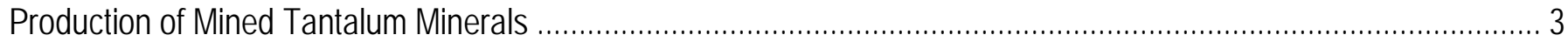

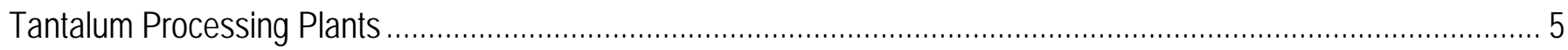

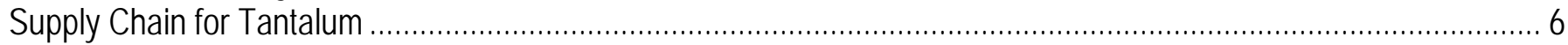

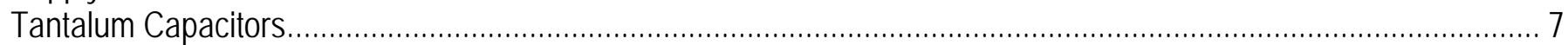

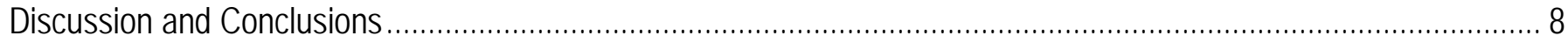

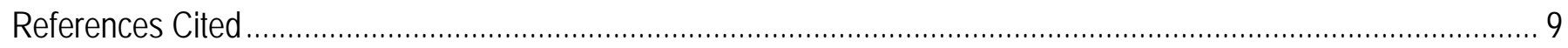

\section{Figures}

1. Chart showing percentage of mined tantalum produced in the world in 2011 , by country. .......................... 14

2. Chart showing refined tantalum $(\mathrm{Ta})$ products, intermediate products manufactured from them,

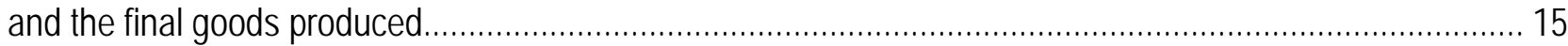

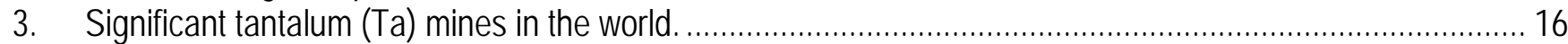

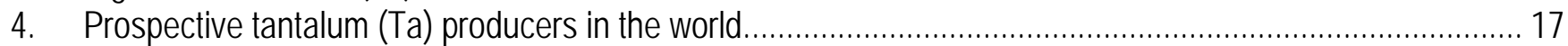

5. Significant tantalum $(\mathrm{Ta})$ fabricators and refineries in the world. ......................................................... 18

6. Chart showing the relationship of selected tantalum ( $\mathrm{Ta}$ ) mines (or source materials) and processing

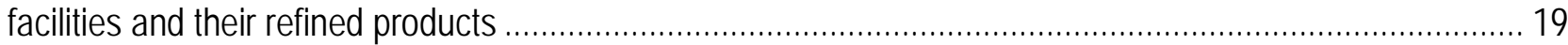

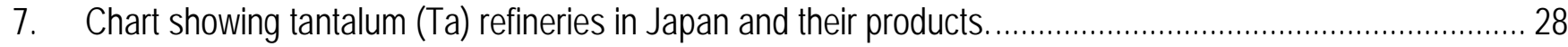

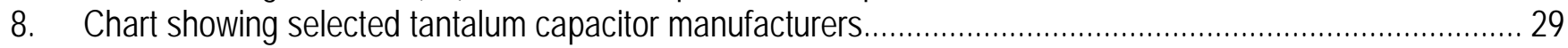

\section{Tables}

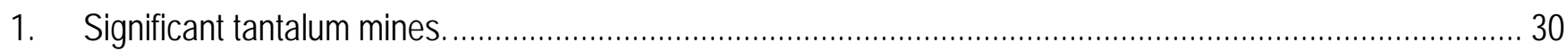

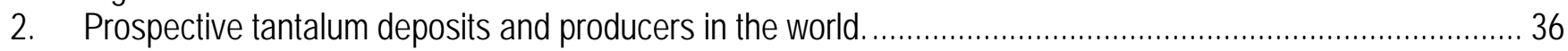

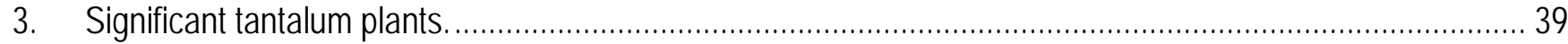

4. Locations of tantalum capacitor manufacturing facilities for three leading manufacturers. ............................. 42

5. Product name, description, and applications for selected tantalum capacitors produced by AVX Corp.......... 43

6. Product name, product description, and applications for selected tantalum ( $\mathrm{Ta}$ ) capacitors produced by KEMET Corp. 


\section{Conversion Factors}

SI to Inch/Pound

\begin{tabular}{lcl}
\hline \multicolumn{1}{c}{ Multiply } & By & \multicolumn{1}{c}{ To obtain } \\
\hline kilometer $(\mathrm{km})$ & Length & \\
meter $(\mathrm{m})$ & 0.6214 & mile $(\mathrm{mi})$ \\
& 1.094 & yard $(\mathrm{yd})$ \\
\hline square kilometer $\left(\mathrm{km}^{2}\right)$ & Area & \\
square kilometer $\left(\mathrm{km}^{2}\right)$ & 247.1 & acre \\
\hline & 0.3861 & square mile $\left(\mathrm{mi}^{2}\right)$ \\
\hline megagram $(\mathrm{Mg}) ;$ metric ton $(\mathrm{t})$ & Mass & \\
metric ton per year & 1.102 & ton, short $(2,000 \mathrm{lb})$ \\
\hline gram per metric ton $(\mathrm{g} / \mathrm{t})$ & 1.102 & ton per year $(\mathrm{t} / \mathrm{yr})$ \\
\hline
\end{tabular}

Temperature in degrees Celsius $\left({ }^{\circ} \mathrm{C}\right)$ may be converted to degrees Fahrenheit $\left({ }^{\circ} \mathrm{F}\right)$ as follows:

${ }^{\circ} \mathrm{F}=\left(1.8 \times^{\circ} \mathrm{C}\right)+32$ 


\title{
An Exploration in Mineral Supply Chain Mapping Using Tantalum as an Example
}

\author{
By Yadira Soto-Viruet, W. David Menzie, John F. Papp, and Thomas R. Yager
}

This report uses the supply chain of tantalum (Ta) to investigate the complexity of mineral and metal supply chains in general and show how they can be mapped. A supply chain is made up of all the manufacturers, suppliers, information networks, and so forth, that provide the materials and parts that go into making up a final product. The mineral portion of the supply chain begins with mineral material in the ground (the ore deposit); extends through a series of processes that include mining, beneficiation, processing (smelting and refining), semimanufacture, and manufacture; and continues through transformation of the mineral ore into concentrates, refined mineral commodities, intermediate forms (such as metals and alloys), component parts, and, finally, complex products. This study analyses the supply chain of tantalum beginning with minerals in the ground to many of the final goods that contain tantalum.

One of the great difficulties to overcome in mapping a supply chain is lack of transparency in the chain-whether it is related to the locations and types of facilities, the materials that the facilities consume and (or) produce, the facilities' production capacities, or the users of the products produced. Not knowing this information presents a significant barrier to understanding the risk of disruption in supply. Also, the geographic distribution of facilities may increase the risk of supply disruption if those facilities are dependent on the same infrastructure.

Supply chain mapping and analysis are tools used to identify the risks of disruption in supply. Each of the facilities that provide key components, perform particular processes, or produce goods is a node on a supply chain map; linkages between nodes are material flow paths. The supply chain nodes and paths constitute the supply chain structure. Singular nodes in a supply chain are unique facilities that provide a key component or perform a key process in the production of a good; they are sometimes called "pinch points."

Disruptions in a supply chain can occur when there is a significant change in the supply structure; the likelihood and possible magnitude of a disruption are determined in part by the characteristics of the chain. A supply chain with multiple facilities that perform each production process or that possess unused capacity (redundancy) is likely to be less subject to disruption-and to be more resilient — than a chain in which only one facility is able to perform a part of the production process or when the facilities in the chain are all operating at full capacity. Although there are significant benefits to redundancy in a supply chain, the cost of building and maintaining redundancy may be large enough to lead organizations to forego those benefits. Failures of production at singular nodes are more likely to cause disruptions in the production of a final good than are failures at redundant nodes. Singular nodes in the supply chain of a good may be difficult to identify, and failures of singular nodes can have surprising results. Multiple linkages suggest redundant material supply routes, implying a more robust supply chain.

A recent example of supply chain disruptions involving the failure of a singular node was owing to a natural disaster - the magnitude 9.0 earthquake and associated tsunami that struck Northern Honshu, Japan, on March 11, 2011. The earthquate and tsunami caused widespread 
devastation across the region, as tens of thousands of people were killed, hundreds of thousands of homes were damaged and (or) destroyed, and the commercial operations of firms were interrupted. The earthquake also disrupted a number of supply chains, so study of the event can provide some perspectives on supply chain disruption.

Northern Honshu is home to a large number of significant mineral production facilities, including nine cement plants, eight iodine plants, four iron and steel plants, four limestone mines, three copper facilities, two gold refineries, two lead refineries, two zinc refineries, one titanium dioxide plant, and one titanium dioxide sponge plant. Damage from the event resulted in a significant reduction in Japan's mineral production. Production of high-purity aluminum, cadmium, smelted and refined copper, and nickel in ferronickel was reduced by more than 10 percent, while production of ferroalloys, gold, lead, steel, silver, and zinc decreased by lesser amounts (Menzie and others, 2011; Kuo, 2013).

Much of the reduction in production was owing to the reduced availability of electricity and damage to important infrastructure, such as roads and ports, which affected the operations of many facilities. In some cases, damage to facilities affected only a particular site. In one case, damages to a singular node had surprising results. Titanium dioxide is used to make paint, and, because of the widespread use of paints, there are many such plants. Therefore, one would not have expected far-reaching consequences to result from damage to a single titanium dioxide plant. The plant in Northern Honshu, however, was the sole supplier of black and red paints used by Ford Motor Co. (United States) for a large number of its vehicles. The damage to the titanium dioxide plant interrupted the production of red and black vehicles of certain models until substitute paints could be identified. In this instance, the titanium dioxide plant constituted a singular node in the production chain (Naughton, 2011; Kuo, 2013).

\section{Physical Properties of Tantalum}

Tantalum is a transition metal with physical and chemical properties that are very similar to those of niobium. A refractory metal, tantalum is ductile, easily fabricated, resistant to corrosion by acids, and a good conductor of heat and electricity. Tantalum is also characterized by high melting and boiling points of 2,996 degrees Celsius $\left({ }^{\circ} \mathrm{C}\right)$ and $5,425^{\circ} \mathrm{C}$, respectively. The abundance of tantalum in the Earth's crust is 0.7 parts per million. Tantalum does not occur naturally as a free metal; however, tantalum occurs in a range of oxide mineral species, including ixiolite, microlite, tantalite, tapiolite, and wodginite. Tantalum-bearing mineral deposits are found in igneous rocks, which include carbonatites, granites, pegmatites, and syenites (British Geological Survey, 2011; Papp, 2012a; Roskill Information Services Ltd., 2012).

\section{World Mine Production}

In 2011, world mine production of tantalum increased by 7 percent to 706 metric tons (t) from $660 \mathrm{t}$ in 2010. Rwanda accounted for 27 percent of total mine production in 2011; Brazil accounted for 20 percent; the Democratic Republic of the Congo [Congo (Kinshasa)], 15 percent; Ethiopia, 14 percent; China, 11 percent; Mozambique, 6 percent; Nigeria, 5 percent; and Burundi, 2 percent (fig. 1; Mobbs, 2012; Papp, 2013; Tse, 2013; Yager, 2013a-c).

The leading producers of tantalum have varied considerably since 2000. Australia, which was the leading producer from 2001 through 2008, ceased production in 2010, although it continues to have large resources of tantalum. For most years between 2001 and 2013, Brazil was the second ranked producer of tantalum. Since 2007, the proportion of production coming from Central Africa has 
increased. In 2011, production from Central Africa accounted for more than 40 percent of world production (Papp, 2009, 2010, 2011, 2012b).

\section{Tantalum Refined Products and End Uses}

Products made of refined tantalum include carbides, ingots, oxides, powders, and metal products, including plates, sheets, rods, and wires. Major industries that consume tantalum include the automotive, ceramic and surface coating, chemicals, construction, engineering, electronics, medical, and metallurgical industries, as well as the military. The electronics and metallurgical industries are the leading users of tantalum. The electronics industry accounts for about 50 to 60 percent of tantalum consumption, and the metallurgical industry accounts for about 20 percent of consumption. In the electronics industry, capacitors, which are the largest single end use for tantalum, accounted for about 40 percent of total tantalum consumption in 2011. Tantalum capacitors are intermediate manufactured products that are used in a variety of final goods, such as automotive electronics, cell phones, hard disc drives, light-emitting diodes, and personal computers. In the metallurgical industry, tantalum superalloys are used mainly in aerospace applications (such as jet engine blades) and land-based gas turbines. These superalloys contain from about 3 to 11 percent tantalum. Metallurgical products include sheets, plates, welded tubes, rods, and wires. These products account for about 8 to 11 percent of tantalum consumption (Roskill Information Services Ltd., 2012). Figure 2 shows the relationship among refined tantalum products, intermediate manufactured products, and final (consumer) goods.

\section{Production of Mined Tantalum Minerals}

Brazil and Rwanda, which were the leading producers of tantalum ore and concentrates in 2011, together accounted for 47 percent of the world's mine production of tantalum. The locations of significant tantalum mines and prospective producers are shown in figures 3 and 4, respectively, and selected deposits and producing areas are briefly discussed below. The mines and prospective producers are identified in tables 1 and 2, respectively, along with their annual capacities, facility type, ownership, and status. The numbers used to identify locations in figures 3 and 4 are keyed to the "ID" in tables 1 and 2 , respectively.

Tantalum production in Australia stopped in 2010; however, Australia contains large resources of tantalum in the Greenbushes and the Wodgina deposits, and production is expected to resume in the future. Greenbushes is located about 250 kilometers $(\mathrm{km})$ from Perth in southwestern Western Australia. The Greenbushes Mine, which is hosted by the Archean Greenbushes pegmatite and includes surface and underground workings, had a production capacity of about 550 metric tons per year (t/yr) of tantalum pentoxide $\left(\mathrm{Ta}_{2} \mathrm{O}_{5}\right)$. The Greenbushes pegmatite contains significant resources of lithium, tantalum, and tin. The Greenbushes operations include a crusher and primary and secondary processing plants, which produce concentrates (Partington, McNaughton, and Williams, 1995; Global Advanced Metals Pty Ltd., 2013a).

Global Advanced Metals Pty Ltd. (GAM) has also mined tantalum at its Wodgina operation, which is located about $100 \mathrm{~km}$ southeast of Port Hedland in the northwestern part of Western Australia. Wodgina had a production capacity of about $250 \mathrm{t} / \mathrm{yr}$ of $\mathrm{Ta}_{2} \mathrm{O}_{5}$ from tantalum-bearing pegmatite at the Mount Cassiterite and the South Tinstone open-cut mines. The Wodgina deposit is hosted in the Archean North Pilbara Craton, which contains at least 120 pegmatites in more than 27 pegmatite groups, including the Wodgina (albite type) and the Mount Cassiterite (albite-spodumene type) pegmatites, which contain high-grade tantalum mineralization. The Wodgina processing plant produces primary tantalum concentrate grading between 8 percent and 19 percent $\mathrm{Ta}_{2} \mathrm{O}_{5}$, which is transported to 
Greenbushes for secondary processing (Sweetapple and Collins, 2002; Global Advanced Metals Pty Ltd., 2013d).

Galaxy Resources Ltd. of Australia owns the Mt. Cattlin Mine, which is located about $2 \mathrm{~km}$ north of Ravensthorpe in Western Australia and has a production capacity of about $25 \mathrm{t} / \mathrm{yr}$ of $\mathrm{Ta}_{2} \mathrm{O}_{5}$. Tantalum ore from Mt. Cattlin is initially processed at the Greenbushes secondary processing plant (Global Advanced Metals Pty Ltd., 2013a).

In Brazil, tantalum production comes largely from the Volta Grande and the Pitinga deposits. At Volta Grande in southern Minas Gerais State, a field of large pegmatites is associated with early Proterozoic granite along the southern margin of the Archean São Francisco Craton. The pegmatites are zoned and contain abundant spodumene. The Volta Grande Mine produces ceramic feldspar, niobium, tantalum, and tin. The tantalum capacity of the Volta Grande Mine is about $25 \mathrm{t} / \mathrm{yr}$ of tantalum concentrate. At the Pitinga deposit in Central Amazonas State in northern Brazil, Paleoproterozoic volcanics of the Iricoume Group and Urupi Formation are intruded by granite plutons of the Madeira Suite, including the Madeira and the Agua Boa plutons. The granite plutons have Rapikivi and biotite granite phases as well as significant metasomatic and hydrothermal alteration. The Pintinga Mine, which is operated by Mineração Taboca S.A., has an annual capacity of about 91 t of $\mathrm{Ta}_{2} \mathrm{O}_{5}(180 \mathrm{t}$ of tantalum concentrate). The company mines columbite ore at the mine and produces a ferroniobiumtantalum alloy that contains 45 percent niobium, 25 percent iron, and 4.2 percent tantalum and is used as a raw material in the production of niobium and tantalum oxide (Lagache and Quéméneur, 1997; Borges and others, 2009; Pohl, 2013; Mineração Taboca S.A., 2013).

The Tanco deposit, which was a leading producer of tantalum from 1969 to 1982 and has a history as a smaller producer since then, is located in southeastern Manitoba Province, Canada. At Tanco, tantalum has been produced from several zones within a pegmatite. Recently, the capacity of Tanco has been about $80 \mathrm{t} / \mathrm{yr}$ of $\mathrm{Ta}_{2} \mathrm{O}_{5}$ (Thomas and Spooner, 1988).

Central Africa - specifically Burundi, Congo (Kinshasa), and Rwanda-was the source of more than 40 percent (more than 300 t) of world primary tantalum production in 2011. In recent years, tantalum and tin have been mined from alluvial and elluvial deposits; however, in the past, lode deposits were mined. The lode deposits are principally quartz veins and pegmatites associated with a series of late- to post-orogenic granites that intrude the Kibara belt, which extends from Katanga Province and Kivu Province in Congo (Kinshasa) into parts of Burundi, Rwanda, and Tanzania, as well as Maniema Province in Congo (Kinshasa). Many of the pegmatites are thought to be small deposits; however, a large zoned pegmatite has been identified at Manono (Pohl, 1994; Kokonyangi, 2004; Dewaele and others, 2010).

The Yichun tantalum-niobium-lithium mine is hosted by a small body of topaz-lepidolite granite that is a fractionated phase of the Yashan batholith in Jiangxi Province, China. The Yichun deposit is the best known of China's tantalum deposits. In Fujian Province, the Nanping pegmatite field also hosts tantalum-niobium-tin mineralization (Yin Lin and others, 1995; Yueqing and Wenying, 1995).

In 2012, Gippsland Ltd. of Australia held 50 percent interest in the Abu Dabbab tantalum-tin deposit in joint-venture with the Egyptian Mineral Resources Co. (50 percent), which is located $770 \mathrm{~km}$ south of Cairo (Petra Capital Pty Ltd., 2012, p. 6). Also in 2012, resources at Abu Dabbab were estimated to be 44.5 million metric tons (Mt) at an average grade of 250 grams per metric ton (g/t) $\mathrm{Ta}_{2} \mathrm{O}_{5}$ and $90 \mathrm{~g} / \mathrm{t}$ tin (Petra Capital Pty Ltd., 2012, p.12). Abu Dabbab is a fine-grained cassiterite and niobium-containing tantalite deposit hosted in altered granitic rocks. The ore zone is about 400 meters (m) long and $200 \mathrm{~m}$ wide and has a depth of $400 \mathrm{~m}$ from the maximum surface elevation (Petra Capital Pty Ltd., 2012, p. 12-13). The deposit is controlled by a northwest-trending shear zone and intersecting north-east structures. The deposit is expected to produce about $420 \mathrm{t}$ of $\mathrm{Ta}_{2} \mathrm{O}_{5}$ in 2016 
(Petra Capital Pty Ltd., 2012, p. 3). In 2010, Gippsland signed an offtake agreement with H.C. Starck $\mathrm{GmbH}$ of Germany, which included the purchase of about $300 \mathrm{t} / \mathrm{yr}$ of contained $\mathrm{Ta}_{2} \mathrm{O}_{5}$ for a period of 10 years (Petra Capital Ltd., 2012, p. 5). Each of the two companies in the joint-venture also held ownership (50 percent each) in the Nuweibi tantalum-tin-feldspar deposit. Indicated and inferred mineral resources at Nuweibi were estimated to be $98 \mathrm{Mt}$ at average grades of $143 \mathrm{~g} / \mathrm{t} \mathrm{Ta} \mathrm{O}_{5}$ and $92 \mathrm{~g} / \mathrm{t}$ niobium (Petra Capital Pty Ltd., 2012, p. 4). The company expected to produce of about 52 t of $\mathrm{Ta}_{2} \mathrm{O}_{5}$ in 2015 and 427 t of $\mathrm{Ta}_{2} \mathrm{O}_{5}$ in 2016 (Petra Capital Pty Ltd., 2012, p. 4).

The Kenticha Mine, which is operated by Ethiopian Mineral Development Share Co. (EMDSC), had an annual capacity of about $90 \mathrm{t}$ of tantalum (which could produce $200 \mathrm{t} / \mathrm{yr}$ of tantalite concentrate grading 45 to 60 percent $\mathrm{Ta}_{2} \mathrm{O}_{5}$ ). The open pit mine is located about $550 \mathrm{~km}$ south of Addis Ababa and is hosted by the Kenticha pegmatite field, which is granitic pegmatite that covers an area of about 2,500 square kilometers $\left(\mathrm{km}^{2}\right)$. At Kenticha, the tantalum-bearing pegmatite deposit is exposed in an area that is more than $2 \mathrm{~km}$ long and 400 to $700 \mathrm{~m}$ wide (Mining Journal, 2011, p. 8; Geological Survey of Ethiopia, 2012, p. 3). The project produces tantalum concentrates composed of columbite-tantalite and other tantalum oxides. In February 2013, EMDSC (through its subsidiary Iris Mining Plc) and its strategic tantalum partner H.C. Starck submitted an Expression of Interest to the Privatization and Public Enterprises Supervising Agency to further develop the Kenticha Mine. Under the proposal, the companies would increase the tantalum reserves, create 12,000 jobs directly and indirectly, and produce high-end products, such as 99-percent-purity tantalum pentoxide powder and capacitor-grade tantalum powder (Business Wire, 2013). The EMDSC envisioned production of $600 \mathrm{t} / \mathrm{yr}$ of tantalite-columbite concentrate; however, no further details as to when these developments might take place were available. The company expected to add hundreds of tons of production from artisanal mines and local cooperatives (Elenilto Minerals \& Mining, 2013).

Noventa Ltd. of the United Kingdom through its subsidiary Highland African Mining Co. Ltd. operated the Marropino niobium and tantalum mine, which is located about $350 \mathrm{~km}$ northeast of Quelimane, Zambezia Province, Mozambique. The mine had an annual production capacity of about 140 t of contained $\mathrm{Ta}_{2} \mathrm{O}_{5}$. The company's project is hosted by the Marropino pegmatite, which is a zoned lithium-rare-metal pegmatite of the lithium-cesium-tantalum family. The Marropino deposit is exposed for a strike length of about $800 \mathrm{~m}$ and a width of about $200 \mathrm{~m}$. The company reported that there is an increase in the tantalum grade toward the center of the deposit. The known mineralization at Marropino is limited to the current area of mining and processing. As of 2010, indicated mineral resources at Marropino were estimated to be $7.40 \mathrm{Mt}$ at an average grade of $223 \mathrm{~g} / \mathrm{t} \mathrm{Ta}_{2} \mathrm{O}_{5}\left(\mathrm{Hains}_{\mathrm{n}}\right.$ and Mounde, 2010, p. 3, 5). In 2010, Noventa signed a 3-year offtake agreement with H.C. Starck for the sale of a substantial portion of its projected production of tantalum concentrate. During 2010, Noventa began shipment of material from the Mozambican Port of Quelimane to Nacala, Thailand, and to the United States (Noventa Ltd., 2011, p. 10, 12 ).

In Russia, tantalum has been mined at the Lovozerskoye deposit on the Kola Peninsula and the Etykinskoye deposit of the Zabaykalskiy mining and beneficiation complex from a massif of nepheline syenite that is enriched in elements, including beryllium, lithium, niobium, tantalum, thorium, rare-earth elements, zirconium, and volatiles, such as chlorine and fluorine. The combined capacity of these two deposits is estimated to be about $10 \mathrm{t} / \mathrm{yr}$ of tantalum ore (Smirnov, 1977).

\section{Tantalum Processing Plants}

As of 2012, at least 10 international companies were engaged in some stage of post-mining tantalum production. Tantalum refiners included Advanced Metallurgical Group N.V. of the Netherlands; GAM of Australia; H.C. Starck of Germany; and Chinese companies 
Congua Tantalum \& Niobium Smelter, Jiangxi Tungsten Group Limited Corp., King-Tan Tantalum Industry Ltd., and Ningxia Non-Ferrous Metal Smelter. Tantalum fabricators included Austrian companies Plansee SE and Treibacher Industrie AG; Heraeus Holding GmbH of Germany, and U.S. companies KEMET Blue Powder Corp. and Molycorp Inc.

Figure 5 shows the locations of significant tantalum fabricators and refineries. The fabricators and refineries are identified in table 3, along with each facility's annual capacity, facility type, ownership, and so forth. The numbers used to identify locations in figure 5 are keyed to the "ID" in table 3.

In January 2012, GAM completed the acquisition of the supermetals business of Cabot Corp. of Boston, Massachusetts, which included tantalum-processing plants in Boyertown, Pennsylvania, and Aizu, Japan. The company integrated the two processing plants with its existing mining and processing operations in Australia. GAM produces tantalum capacitor powders and metallurgical products at its Boyertown plant. Tantalum is often alloyed with tungsten, which improves its mechanical properties and strength but retains the fabricateability of pure tantalum. GAM's tantalum metallurgical products, which may be produced as foil, sheet, plate, wire, rod, tube, and metallurgical-grade powder, include tungsten alloy containing 2.5 percent tantalum and tungsten alloy containing 10 percent tantalum. The company's primary tantalum concentrate supply was the Wodgina Mine in northwestern Western Australia (Global Advanced Metals Pty Ltd., 2012; 2013 a-c; Roskill Information Services Ltd., 2012).

In February 2012, the capacitor manufacturer KEMET Corp. of Greenville, South Carolina, signed an agreement to acquire Niotan Inc. of Carson City, Nevada, which had been a significant supplier of tantalum powder to KEMET for several years. The Niotan tantalum fabrication facility was renamed KEMET Blue Powder. KEMET reported the acquisition to be part of its strategy to secure and stabilize its supply of tantalum raw material. In March 2012, the company also reported exclusive rights to secure raw material from Tantalite Resources of South Africa, which is a new supplier that would process conflict-free ore from the Kisenge Mine in Katanga Province in Congo (Kinshasa) (KEMET Corp., 2012a, c; Roskill Information Services Ltd., 2012).

In 2011, Molycorp Inc. of Greenwood Village, Colorado, acquired a 90 percent interest in the AS Silmet facility located in Sillamae, Estonia; this facility is one of the leading producers of tantalum metal in Europe. The processing plant manufactures tantalum hydroxides, oxides, and metals (Molycorp Inc., 2011).

King-Tan Tantalum Industry Ltd. produces tantalum bars, carbides, ingots, oxides, and powders. King-Tan, which is located in Jiangxi Province, China, sells its products to domestic and international customers, including customers in Germany, Japan, Singapore, and the United States (King-Tan Tantalum Industry Ltd., 2009a, b).

\section{Supply Chain for Tantalum}

The tantalum supply chain begins with the mining of ore and ends with the manufacture of consumer products or goods. The supply chain includes the mines, smelters, and refineries identified in figures 3, 4, and 5 and tables 1, 2, and 3 and extends downstream to include fabricators and manufacturers of intermediate and consumer goods, of which the significant ones are identified in figure 5 and table 3. Any disruption along the supply chain can result in higher prices that could affect many industries and, potentially, the availability of final goods. Identifying connections between the raw materials and the downstream entities that produce products that contain tantalum is critical to mapping the supply chain and analyzing the likelihood of supply disruption.

Sources of tantalum include artisanal mining, conventional (surface and underground) mining operations, and the recovery of tantalum from slag from tin smelting operations and from scrap 
recycling. Based on data from Roskill Information Services Ltd., mining operations accounted for about 74 percent of the tantalum supply in 2011, followed by 18 percent from scrap recycling and 8 percent from tin slags (Roskill Information Services Ltd., 2012). Conventional hard rock mines around the world include surface and underground mines in Australia, Brazil, Canada, and Russia. Production from Burundi, Congo (Kinshasa), and Rwanda is mostly from artisanal mining of placer deposits. After the extraction of the raw material, the ore is physically concentrated by gravity separation and then processed by a smelter and refinery to obtain refined products, which include tantalum metals, oxides, and powders. For example, portions of tantalum concentrate mined from the Kenticha, the Volta Grande (Fluminese), and the Marropino Mines were sent to H.C. Starck in Germany for refining into tantalum fabricated products, such as foils, ingots, plates, rods, sheets, and tubes, and tantalum powder and compounds, which included carbides and oxides.

Figure 6 shows examples of the relationships among selected tantalum producing mines or source materials, and processing facilities and their refined products for selected countries. Those entries for which the information given is speculative or uncertain are marked with a question mark. Figure 7 lists tantalum processing facilities in Japan along with the refined products they produce.

\section{Tantalum Capacitors}

One of the main uses of tantalum is in capacitors. Capacitors are used to store electrical charge for later use and are common to all types of electronic equipment, including that used in automobiles, cameras, computers, engine management systems, light-emitting diodes, and cell phones and other telecommunications equipment. The authors identified 25 companies engaged in the manufacture of tantalum capacitors: including Ningxia Orient Tantalum Industry Co. Ltd. of China; NEC TOKIN Corp. of Japan; Samsung Electro-Mechanics of the Republic of Korea; and U.S. companies AVX Corp., KEMET, and Vishay Intertechnology Inc. (fig. 8). As of 2012, leading tantalum capacitor producers included AVX, which accounted for about 30 percent of the total market value, KEMET, NEC TOKIN, and Vishay. AVX manufactures tantalum capacitors for automobile, aerospace, and medical applications (KEMET Corp., 2012a, c; Roskill Information Services Ltd., 2012; AVX Corp., 2013a).

Table 4 presents the location of the facilities at which AVX, KEMET, and NEC TOKIN manufacture tantalum capacitors. AVX and KEMET each have five manufacturing sites, and NEC TOKIN has seven sites. All three companies have facilities in geographically diverse areas.

AVX produces about 10 different series of capacitors, which are used in a variety of aerospace, medical, and military applications (table 5). KEMET's product list includes 85 capacitor series. Series differ based upon a number of characteristics, including composition of the capacitor, electrical characteristics, reliability, the temperature at which they will operate, and how they may be mounted in a product (table 6).

Clearly, there are a large number of manufacturers, facilities, and types of capacitors. The large number of producing companies, manufacturing facilities, and types of capacitors contributes to the complexity of estimating the probability of a disruption of the supply of final goods that contain Ta-bearing capacitors. One would need to understand the relationship between manufacturing facilites and the types of capacitors they produce to evaluate the likelihood that a disruption at a plant might disrupt production of final goods that use a particular type of capacitor. Further, one would need to know if the type of capacitor used in a particular product could be replaced by one of the many other types of capacitors. The large number of potential combinations of plants, capacitor types, and potential substitution between types of capacitors makes estimation of the probability of disruption of a supply chain at the stage of capacitor manufacture a daunting task. 


\section{Discussion and Conclusions}

The present investigation of the supply chain of tantalum, although only partial with regard to the products that use or depend on tantalum, the facilities that manufacture tantalum-containing products, and which products can substitute for one another, demonstrates several important points and provides some perspectives concerning the strategies that might be employed to map supply chains. First, supply chains, when considered in their entirety (from material in the earth to the final consumer product), are incredibly complex, and reducing this complexity to a manageable level requires clearly defined questions that partition the complex supply chain into manageable parts. For example, questions about how a disruption in the supply of a key input may affect the availability of end products that use that input will be quite different than questions about what is the likelihood that a particular good could suffer a particular supply disruption. In the former case, the level of complexity at the beginning of the supply chain (mining and initial processing of mineral material) is relatively limited, as mining and mineral processing sites are relatively few and knowable. The number of final goods, their component parts, and the facilities in which they are manufactured is considerably larger, however. If supply chain disruption is approached from the end of the chain - that is, if one wants to know what is the likelihood that there will be a disruption in the availability of a particular final good-the number of final goods one must analyze is reduced but the number of initial mineral materials that must be considered will be large. Although one may limit the complexity by focusing on one part of the chain based upon the question asked, the complexity in other parts of the supply chain may not be reduced. Defining the question clearly still may not reduce some types of complexity, such as the number of particular products and the extent to which they can substitute for one another. A supply chain "map," then, must be designed to answer particular questions, and those questions will determine the level of detail that the supply chain map needs to contain to answer the questions. This is very much analogous to the approach used with topographic and geologic maps, which, depending on the scale of the map, contain more or less detail about land forms and geology of the mapped entity. To determine the likelihood that the supply chain of a particular product could be disrupted, a very detailed analysis of the supply chain involving all materials and their subsequent transformations and potential substitutes is necessary. Such an analysis is expensive to perform and can become obsolete if part of the production process for that good changes, and so, a detailed map of a supply chain is usually not available. The question then becomes at what 'scale' a supply chain map can be prepared that will be of use in evaluating the vulnerability of supply chain disruption without fully mapping the chain.

In the case of tantalum, there are a few mines that produce tantalum minerals; however, those mines supply several processing facilities, directly or through traders. Refined mineral products are further processed to make chemicals, metals (or alloys), or simply a more-refined mineral (that is, greater purity and (or) more controlled physical properties, such as particle size). Metals and chemicals can go through several steps while being incorporated into a product, and the number of facilities involved often increases. So, tantalum starts with a few facilities (mines), passes through a complex web of facilities, and then becomes incorporated in a large number of products. The increasing number of facilities, material paths, and buyer-seller needs (as they relate to material requirements) result in greater complexity as one moves down the supply chain from mining to consumer product.

At some point in the supply chain, material requirements are replaced by performance criteria, which further complicates analysis. Take, for example, the large number of tantalum capacitors described in the capacitor section of this report. Looking backwards through the supply chain (that is, from product to material source) is a useful way to analyze risk. Bear in mind, however, that not all supply paths are connected or overlap. Materials in the early part of the supply chain (for example, minerals) have more possible uses than materials at the end of the supply chain (for example, cell 
phones and turbine engines). As a result, a supply disruption at the beginning of the supply chain can have a broader effect as material changes paths among processing facilities than would a supply disruption at the downstream end of the supply chain. On the other hand, a downstream interruption affects fewer products. It is possible that certain products depend on materials that follow a path through one facility, making that facility critical to that product; that is, a "pinch point" in the supply chain.

Many supply chain maps produced to date have focused on the front end of the chain; that is, the extraction of mineral materials and their initial processing, and provide a list of final goods that may contain those materials (European Commission Enterprise and Industry Directorate, 2010). Such an approach typically focuses on the degree of concentration of the production of mineral materials. This is useful for identifying those materials that are more likely to be subject to disruption. These maps, however, provide only very general information about the downstream parts of the supply chain. What is needed is information that could be applied to a number of different end products. One such approach would be to gather information on key technologies that are used in a large number of final goods. This approach still entails considerable work as the situation with tantalum-containing capacitors demonstrates. It can, however, provide information on the downstream parts of the supply chains of a large number of final goods. It can also map which products are connected to which mines through which processing facilities.

Another issue is how best to present information about material flow that is useful in identifying risk and is understandable. In this report, maps show geographic facility location and charts show connections between producers and in the supply chain that may be linked by ownership, investment connection, and (or) purchase contracts.

Other factors that contribute to supply risk but that are not included in this report are commercial infrastructure (for example, competent manpower, electrical power supply, and transportation) and good governance (for example, the legal infrastructure and the business friendly nature of the geographic area).

\section{References Cited}

AVX Corp., 2013a, AVX Categories_Capacitors-Tantalum: Fountain Inn, South Carolina, AVX Corp. (Accessed May 17, 2013, at http://www.avx.com/prodinfo_catlist.asp?ParentID=48.) AVX Corp., 2013b, AVX tantalum: Fountain Inn, South Carolina, AVX Corp., May, 3 p. (Accessed June 25, 2013, at http://www.avx.com/docs/Catalogs/tantintr.pdf.)

Borges, R.M.K., Villas, R.N.N., Fuzikawa, K., Dall’Agnol, R., Pimenta, M.A., 2009, Phase separation, fluid mixing, and origin of the greisens and potassic episyenite associated with the Água Boa pluton, Pitinga tin province, Amazonian Craton, Brazil: Journal of South American Earth Sciences, v. 27, issue 2-3, February, p. 161-183.

British Geological Survey, 2011, Niobium-tantalum: Nottingham, United Kingdom, British Geological Survey, April, 27 p. (Accessed August 7, 2013, at http://www.bgs.ac.uk/downloads/start.cfm?id=2033.)

Business Wire, 2013, Elenilto \& H.C. Starck bid to develop the Kenticha’s tantalum mine: London, United Kingdom, Business Wire, February 18. (Accessed March 17, 2013, at http://www.businesswire.com/news/home/20130218005545/en/Elenilto-H.C.-Starck-Bid-DevelopKenticha\%E2\%80\%99s-Tantalum.)

Dewaele, S., De Clercq, F., Muchez, P., Schneider, J., Burgess, R., Boyce, A., and

Fernandez-Alonso, M., 2010, Geology of the cassiterite mineralization in the Rutongo area, Rwanda (Central Africa)—Current state of knowledge: Geologica Belgica, v. 13, issue 1-2, p. 91-112. 
Elenilto Minerals \& Mining, 2013, Ethiopia-Kenticha tantalum project: London, United Kingdom, Elenilto Minerals \& Mining. (Accessed March 17, 2013, at http://www.elenilto.com/projects/ tantalum-niobium/ethiopia-bupo-kilkile/.)

European Commission Enterprise and Industry Directorate, 2010, Critical raw materials for the EUReport of the ad-hoc working group on defining critical raw materials: European Commission, July 30, 85 p. (Accessed June 20, 2013, at http://ec.europa.eu/enterprise/policies/ raw-materials/files/docs/report-b_en.pdf.)

Geological Survey of Ethiopia, 2012, Tantalum-Key mineral for gadgets and electronic equipment: Addis Ababa, Ethiopia, Geological Survey of Ethiopia, January, 4 p. (Accessed August 7, 2013, at http://extra.geus.info/cet/ethiopia/EthiopienBlad_TANTALUM.pdf.)

Global Advanced Metals Pty Ltd., 2012, Acquisition of Cabot Supermetals completed: West Perth, Western Australia, Australia, Global Advanced Metals Pty Ltd. media release, January 23, 2 p. (Accessed April 16, 2013, at http://www.globaladvancedmetals.com/media/29722/ supermetals acquisition completed 23 jan 2012.pdf.)

Global Advanced Metals Pty Ltd., 2013a, Greenbushes-Australia: Global Advanced Metals Pty Ltd. (Accessed June 17, 2013, at http://www.globaladvancedmetals.com/our-operations/ gam-resources/greenbushes-australia.aspx.)

Global Advanced Metals Pty Ltd., 2013b, Tantalum concentrate: Global Advanced Metals Pty Ltd. (Accessed April 16, 2013, at http://www.globaladvancedmetals.com/our-products/ tantalum-concentrate.aspx.)

Global Advanced Metals Pty Ltd., 2013c, Tantalum metallurgical products: Global Advanced Metals Pty Ltd. (Accessed April 16, 2013, at http://www.globaladvancedmetals.com/our-products/ tantalum-metallurgical-products.aspx.)

Global Advanced Metals Pty Ltd., 2013d, Wodgina-Australia: Global Advanced Metals Pty Ltd. (Accessed April 16, 2013, at http://www.globaladvancedmetals.com/our-operations/ gam-resources/wodgina-australia.aspx.)

Hains, D.H., and Mounde, Mark, 2010, Technical report on the Marropino project and associated properties, Zambezia Province, Mozambique-NI 43-101 technical report, prepared for Noventa Ltd.: Toronto, Ontario, Canada, Scott Wilson Roscoe Postle Associates Inc., 197 p. plus 3 appendixes. (Accessed June 13, 2013, at http://www.noventagroup.com/wp-content/ uploads/pdf/SW_43-101_Noventa-Report-Oct-15-2010.pdf.)

KEMET Corp., 2012a, KEMET Blue Powder Corporation meets all conflict-free smelter site requirements: Greenville, South Carolina, KEMET Corp., March 1. (Accessed April 12, 2013, at http://www.kemet.com/page/new2012512.)

KEMET Corp., 2012b, KEMET signs agreement to acquire 34\% interest in NEC TOKIN_Option to acquire 100\% ownership: Greenville, South Carolina, KEMET Corp., March 12. (Accessed July 25, 2013, at http://www.kemet.com/page/new2012515.)

KEMET Corp., 2012c, KEMET signs agreement to acquire Niotan Incorporated: Greenville, South Carolina, KEMET Corp., February 2, 1 p. (Accessed April 9, 2013, at http://www.kemet.com/page/new2012504.)

KEMET Corp., 2012d, Setting the course for success-Annual report 2012: Simpsonville, South Carolina, KEMET Corp., 141 p. (Accessed June 25, 2013, at http://b2icontent.irpass.cc/2072\%2F137048.pdf?AWSAccessKeyId=1Y51NDPSZK99KT3F8VG2\& Expires=1372271139\&Signature=Jc\%2FVrd4kvts7dffcaeMJ2g1VbG4\%3D.) 
KEMET Corp., 2013a, Product selection guide: Simpsonville, South Carolina, KEMET Corp., 64 p.

(Accessed May 17, 2013, at

http://www.kemet.com/kemet/web/homepage/kechome.nsf/file/2013_Product_Selection_Guide/\$file/

2013_Product_Selection_Guide.pdf.)

KEMET Corp., 2013b, Tantalum capacitors: Simpsonville, South Carolina, KEMET Corp. (Accessed

August 9, 2013, at http://www.kemet.com/kemet/web/homepage/kechome.nsf/weben/

Tantalum Capacitors.)

King-Tan Tantalum Industry Ltd., 2009a, Product list: Yifeng, Jiangxi, China, King-Tan Tantalum

Industry Ltd. (Accessed April 17, 2013, at http://www.king-tan.com/products_list.html.)

King-Tan Tantalum Industry Ltd., 2009b, Sales: Yifeng, Jiangxi, China, King-Tan Tantalum Industry Ltd. (Accessed April 17, 2013, at http://www.king-tan.com/comcontent_detail/

\&FrontComContent_list01-001CurrentIds=08f3375a-fdb0-4462-a221-ad36b003da35_9fd56becd07d-4f85-aa15-f3b3fedaa80e\&comContentId=9fd56bec-d07d-4f85-aa15-

f3b3fedaa80e\&comp_stats=comp-FrontComContent_list01-001.html.)

Kokonyangi, 2004, Structural constraints on cassiterite and colombite-tantalite mineralization in the

Kibaran belt, D.R. Congo (Central Africa)_-Implication for the timing of ore formation: Journal of Geoscience, v. 47, no. 11, March, p.127-140.

Kuo, C.S., 2013, The mineral industry of Mozambique, in Area reports-International—Asia and the Pacific: U.S. Geological Survey Minerals Yearbook 2011, v. III, p. 13.1-13.13.

Lagache, Martine, and Quéméneur, Joël, 1997, The Volta Grande pegmatites, Minas Gerais, Brazil—An example of rare-element granitic pegmatites exceptionally enriched in lithium and rubidium: The Canadian Mineralogist, v. 35, p. 135-165.

Menzie, W.D., Baker, M.S., Bleiwas, D.I., and Kuo, Chin, 2011, Mines and mineral processing facilities in the vicinity of the March 11, 2011, earthquake in northern Honshu, Japan: U.S. Geological Survey Open-File Report 2011-1069, 7 p. (Accessed June 20, 2013, at http://pubs.usgs.gov/of/2011/1069/.)

Mineração Taboca S.A., 2013, Products-Ferro-niobium-tantalum alloy (FeNbTa): Mineração Taboca S.A. (Accessed May 8, 2013, at http://www.mtaboca.com.br/eng/produtos/liga.asp.)

Mining Journal, 2011, Ethiopia-A supplement to Mining Journal: London, United Kingdom, Mining Journal special edition, January, 15 p. (Accessed March 25, 2013, at http://www.mining-journal.com/ _data/assets/supplement_file_attachment/0018/251217/Ethiopia_scr.pdf.)

Mobbs, P.M., 2012, The mineral industry of Nigeria, in Area reports-International_-Africa and Middle East: U.S. Geological Survey Minerals Yearbook 2011, v. III, p. 33.1-33.4.

Molycorp Inc., 2011, Molycorp acquires controlling stake in AS Silmet, expands operations to Europe, doubles near-term rare earth oxide production capacity: Greenwood Village, Colorado, and Tallin, Estonia, Molycorp Inc. news release, April 4. (Accessed April 12, 2013, at http://www.molycorp.com/molycorp-acquires-controlling-stake-in-as-silmet-expands-operations-toeurope-doubles-near-term-rare-earth-oxide-production-capacity-2.)

Naughton, Keith, 2011, Ford curbs black, red paint use amid Japan quake shortage: Bloomberg L.P., March 24. (Accessed June 20, 2013, at http://www.bloomberg.com/news/2011-03-24/

ford-limits-use-of-black-red-paints-amid-japan-quake-shortage.html.)

NEC TOKIN Corp., 2013, Domestic network: NEC TOKIN Corp. (Accessed June 25, 2013, at http://www.nec-tokin.com/english/info/network.html.)

Noventa Ltd., 2011, Annual report and financial statements 2010: Saint Helier, Jersey [United Kingdom], Noventa Ltd., February 3, 96 p. (Accessed March 25, 2013, at http://www.noventagroup.com/wp-content/uploads/pdf/04022011-Noventa-RA-2010.pdf.) 
Papp, J.F., 2009, Tantalum: U.S. Geological Survey Mineral Commodity Summaries 2009, p. 164-165.

Papp, J.F., 2010, Tantalum: U.S. Geological Survey Mineral Commodity Summaries 2010, p. 162-163.

Papp, J.F., 2011, Tantalum: U.S. Geological Survey Mineral Commodity Summaries 2011, p. 162-163.

Papp, J.F., 2012a, Niobium (columbium) and tantalum, in Metals and minerals: U.S. Geological Survey Minerals Yearbook 2011, v. I, p. 52.1-52.14. (Accessed July 30, 2013, at http://minerals.usgs.gov/minerals/pubs/commodity/niobium/myb1-2011-niobi.pdf.)

Papp, J.F., 2012b, Tantalum: U.S. Geological Survey Mineral Commodity Summaries 2012, p. $162-163$.

Papp, J.F., 2013, Tantalum: U.S. Geological Survey Mineral Commodity Summaries 2013, p. 162-163.

Partington, G.A., McNaughton, N.J., and Williams, I.S., 1995, A review of the geology, mineralization, and geochronology of the Greenbushes pegmatite, Western Australia: Economic Geology, v. 90, issue 3, p. 616-635.

Petra Capital Pty Ltd., 2012, Gippsland Ltd._-Emerging “tier 1” tantalum-tin producer: Sydney, New South Wales, Australia, Petra Capital Pty Ltd., 20 p. plus 4 appendixes.

Pohl, W.L., 1994, Metallogeny of the northeastern Kibara belt, Central Africa-Recent perspectives: Ore Geology Reviews, v. 9, no. 2, p. 105-130. DOI: http://dx.doi.org/10.1016/0169-1368(94)90024-8.

Pohl, W.L., 2013, Economic geology of metals, chap. 2 of Economic geology, principles and practiceMetals, minerals, coal and hydrocarbons-An introduction to formation and sustainable exploration of mineral deposits: Oxford, United Kingdom, Wiley-Blackwell, 680 p. (Accessed July 25, 2013, via http://onlinelibrary.wiley.com/doi/10.1002/9781444394870/.)

DOI: http://dx.doi.org/10.1002/9781444394870

Roskill Information Services Ltd., 2012, Tantalum-Market outlook to 2016: London, United Kingdom, Roskill Information Services Ltd., 164 p.

Smirnov, V.I.,ed., 1977, Ore deposits of the USSR: London, United Kingdom, Pitman Publishing Ltd., v. III, 492 p.

Sweetapple, M.T., and Collins, P.L.F., 2002, Genetic framework for the classification and distribution of Archean rare metal pegmatites in the North Pilbara Craton, Western Australia, Economic Geology, v. 97, no. 4, p. 873-895. DOI: http://dx.doi.org/10.2113/gsecongeo.97.4.873.

Tantalum-Niobium International Study Center, 2013, Tantalum—Raw materials and processing: Tantalum-Niobium International Study Center. (Accessed September 25, 2013, at http://tanb.org/tantalum.)

Thomas, A.V., and Spooner, E.T.C., 1988, Occurrence, petrology and fluid inclusion characteristics of tantalum mineralization in the Tanco granitic pegmatite southeastern Manitoba, in Taylor R.P., and Strong D.F., Recent advances in the geology of granite-related mineral deposits: Montreal, Quebec, Canada, Canadian Institute of Mining and Metallurgy, v. 39, p. 208-221.

Tse, Pui-Kwan, 2013, The mineral industry of China, in Area reports-International-Asia and the Pacific: U.S. Geological Survey Minerals Yearbook 2011, v. III, p. 9.1-9.27.

Yager, T.R., 2013a, The mineral industry of Congo (Kinshasa), in Area reports-International_Africa and Middle East: U.S. Geological Survey Minerals Yearbook 2011, v. III, p. 11.1-11.9.

Yager, T.R., 2013b, The mineral industry of Mozambique, in Area reports-International_Africa and Middle East: U.S. Geological Survey Minerals Yearbook 2011, v. III, p. 31.1-31.6.

Yager, T.R., 2013c, The mineral industry of Rwanda, in Area reports-International-Africa and Middle East: U.S. Geological Survey Minerals Yearbook 2011, v. III, p. 34.1-34.4. 
Yin Lin, Pollard, P.J., Shouxi, Hu, and Taylor, R.G., 1995, Geologic and geochemical characteristics of the Yichun Ta-Nb-Li deposit, Jiangxi Province, South China: Economic Geology and the Bulletin of the Society of Economic Geologists, v. 90, no. 3, p. 577-585.

DOI: http://dx.doi.org/10.2113/gsecongeo.90.3.577.

Yueqing, Yang, and Wenying, Wang., 1995, Ta-Nb-Sn mineralization in the Nanping granitic pegmatite, Fujian, China, in Wang, Sijing, Scientia Geologica Sinica: Beijing, China, Science Press, v. 4, no. 2, p. 193-209. 


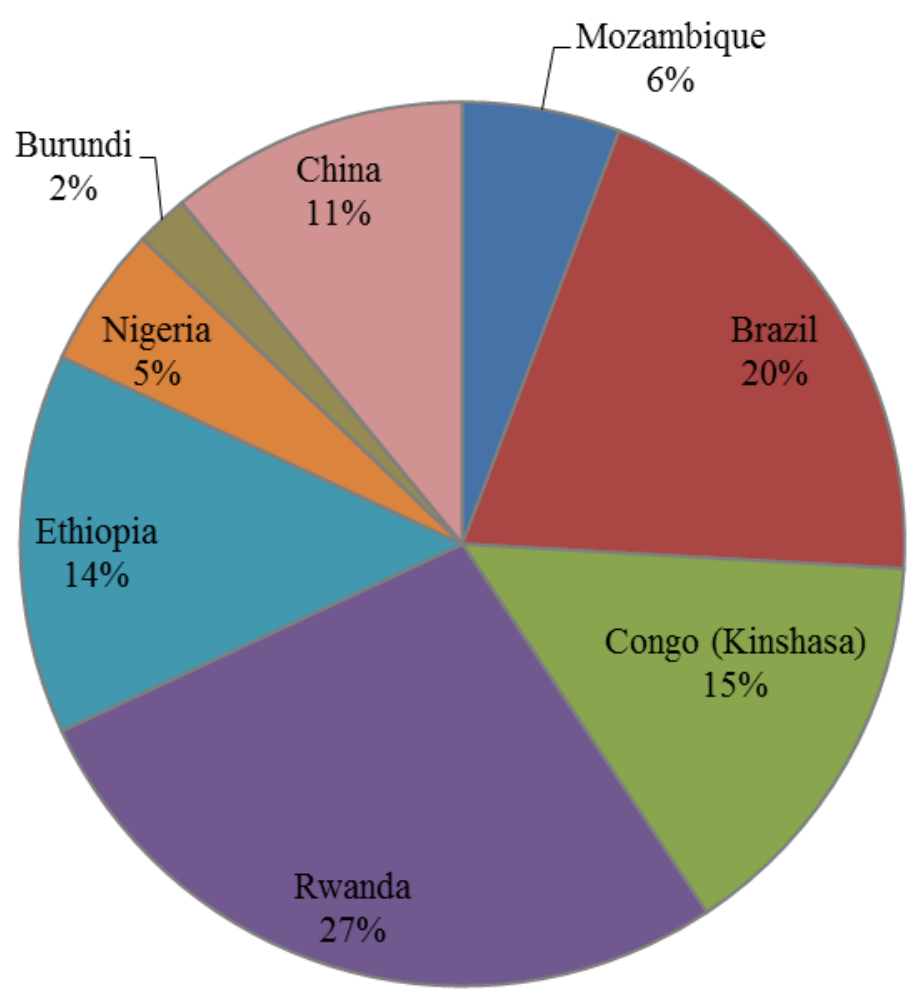

Figure 1. Chart showing percentage of mined tantalum produced in the world in 2011, by country. The amount of contained tantalum in the ore totaled 706 metric tons. Data are from Mobbs (2012), Papp (2013), Tse (2013), and Yager $(2013 a-c)$. 


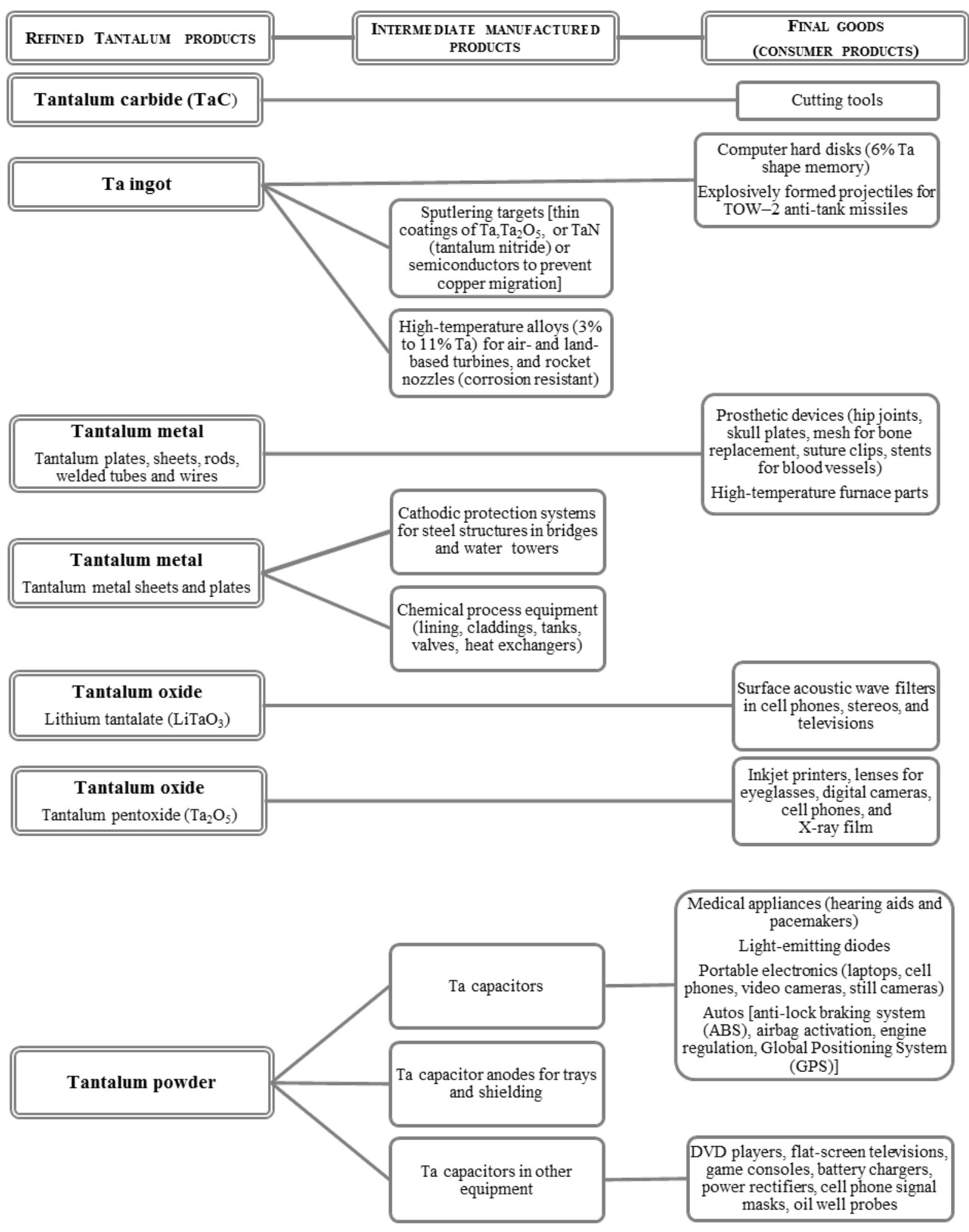

Figure 2. Chart showing refined tantalum $(\mathrm{Ta})$ products, intermediate products manufactured from them, and the final goods produced (British Geological Survey, 2011; Tantalum-Niobium International Study Center, 2013). 


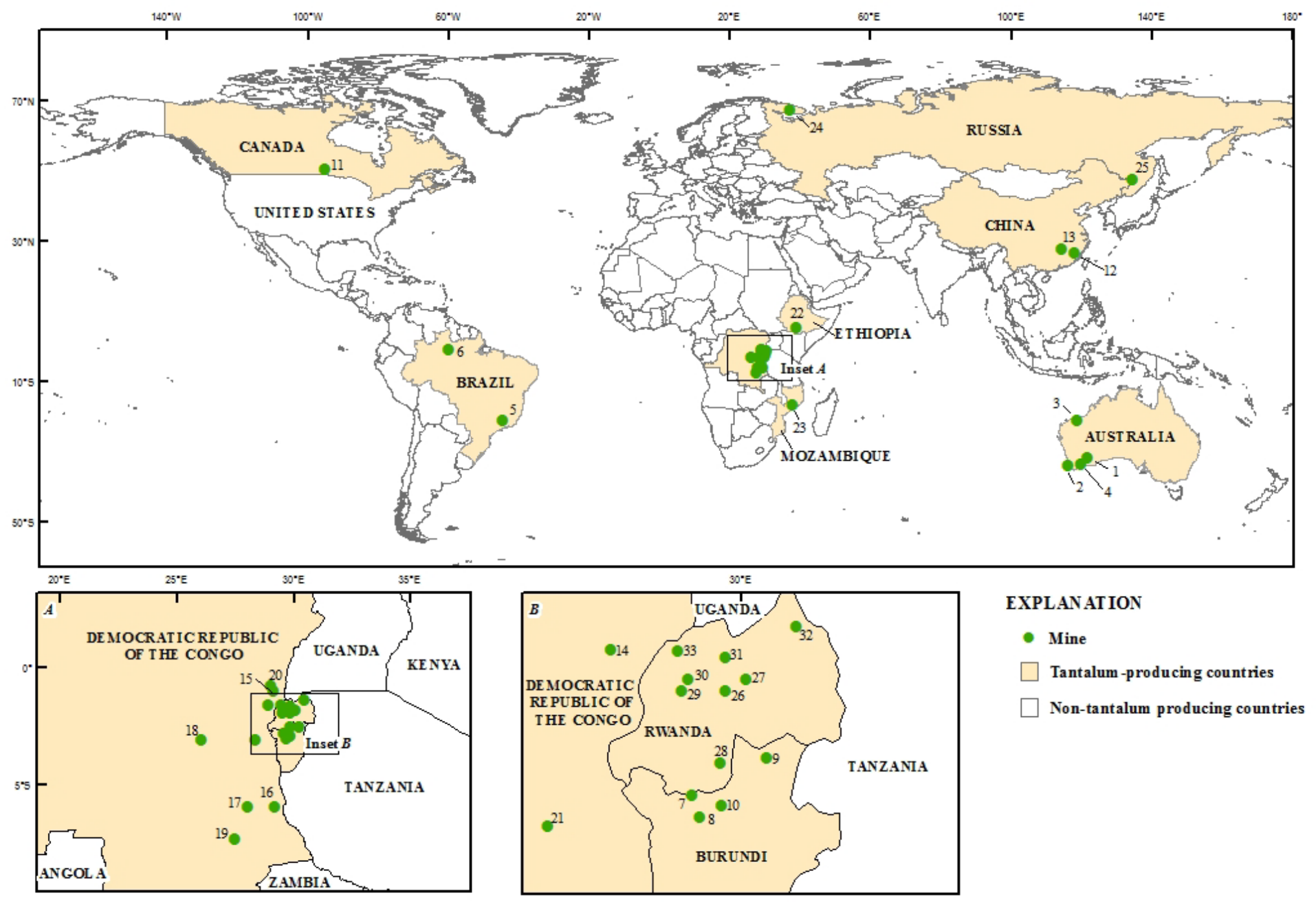

Figure 3. Significant tantalum (Ta) mines in the world. Insets $A$ an $B$ show the location of Ta mines in Burundi, the Democratic Republic of the Congo [Congo (Kinshasa)], and Rwanda in detail. The numbers used to identify locations are keyed to the "ID" in table 1. 

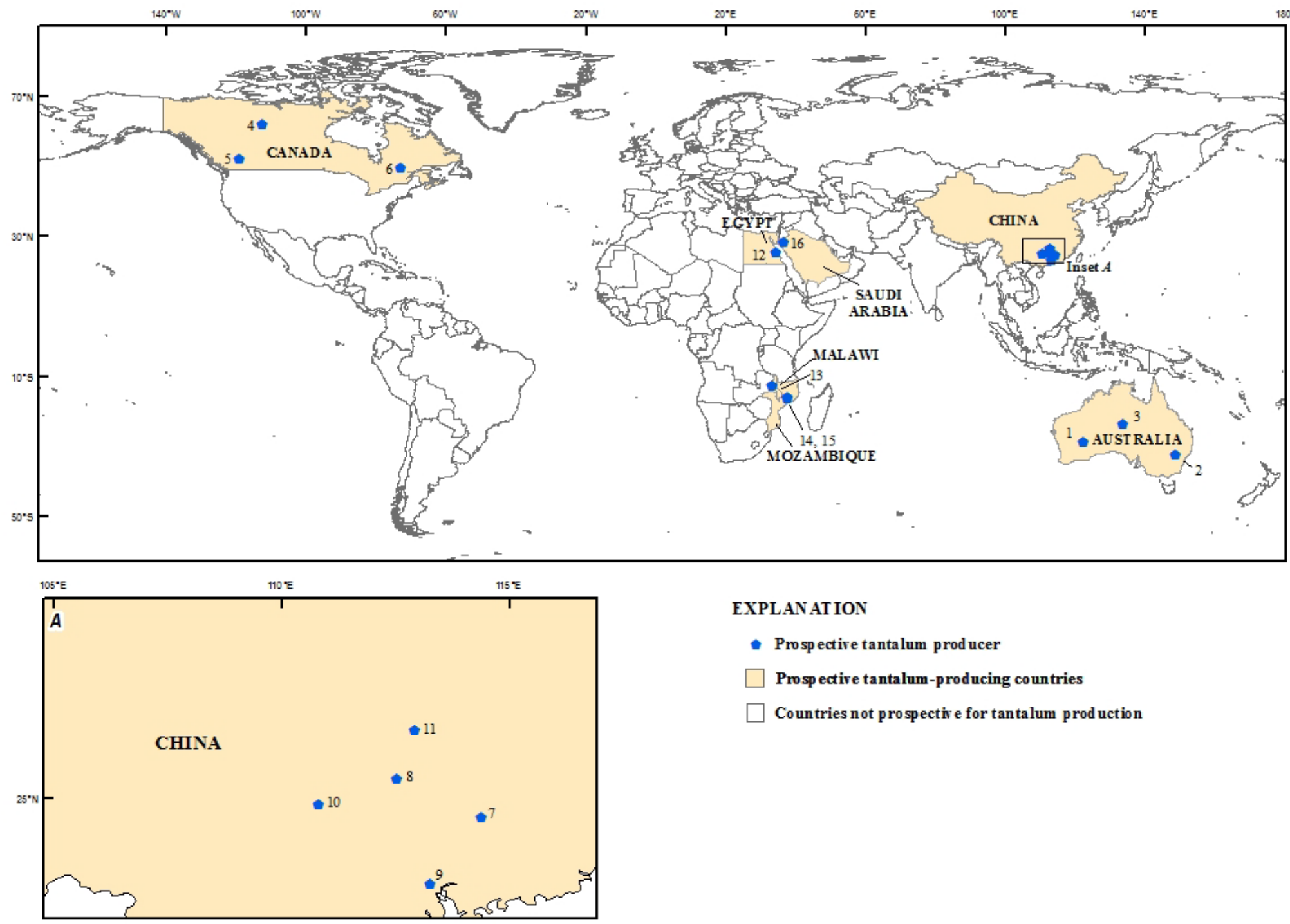

\section{EXPLANATION}

- Prospective tantalum producer

$\square$ Prosp ective tantalum-producing countries

$\square$ Countries not prospectiv e for tantalum production

Figure 4. Prospective tantalum (Ta) producers in the world. Inset $A$ shows the locations of prospective producers in China in detail. The numbers used to identify locations are keyed to the "ID" in table 2. 


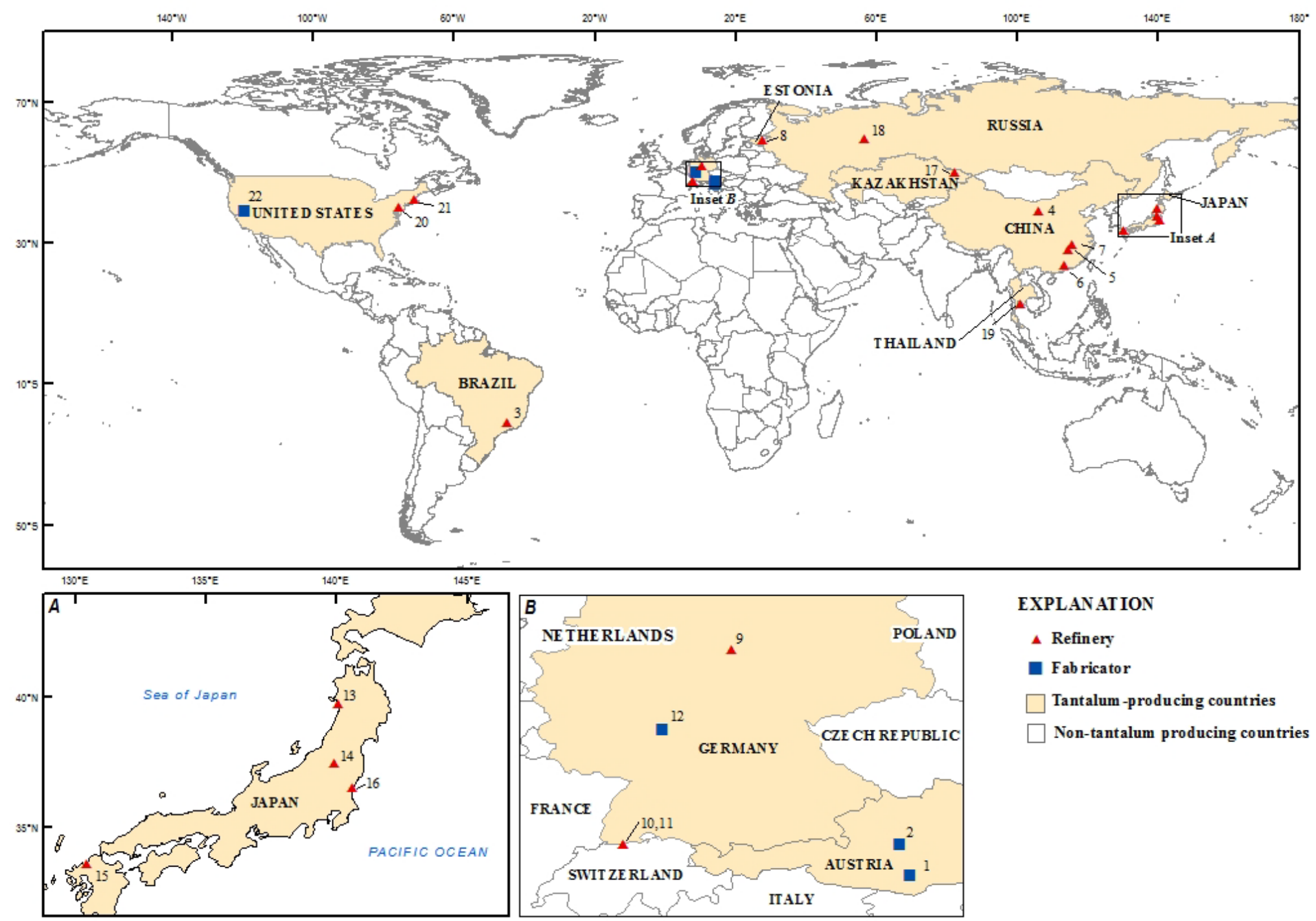

Figure 5. Significant tantalum (Ta) fabricators and refineries in the world. Inset $A$ shows the locations of Ta refineries in Japan in detail. Inset $B$ shows the locations of Ta fabricators and refineries in Austria and Germany in detail. The numbers used to identify locations are keyed to the "ID" in table 3. 
A
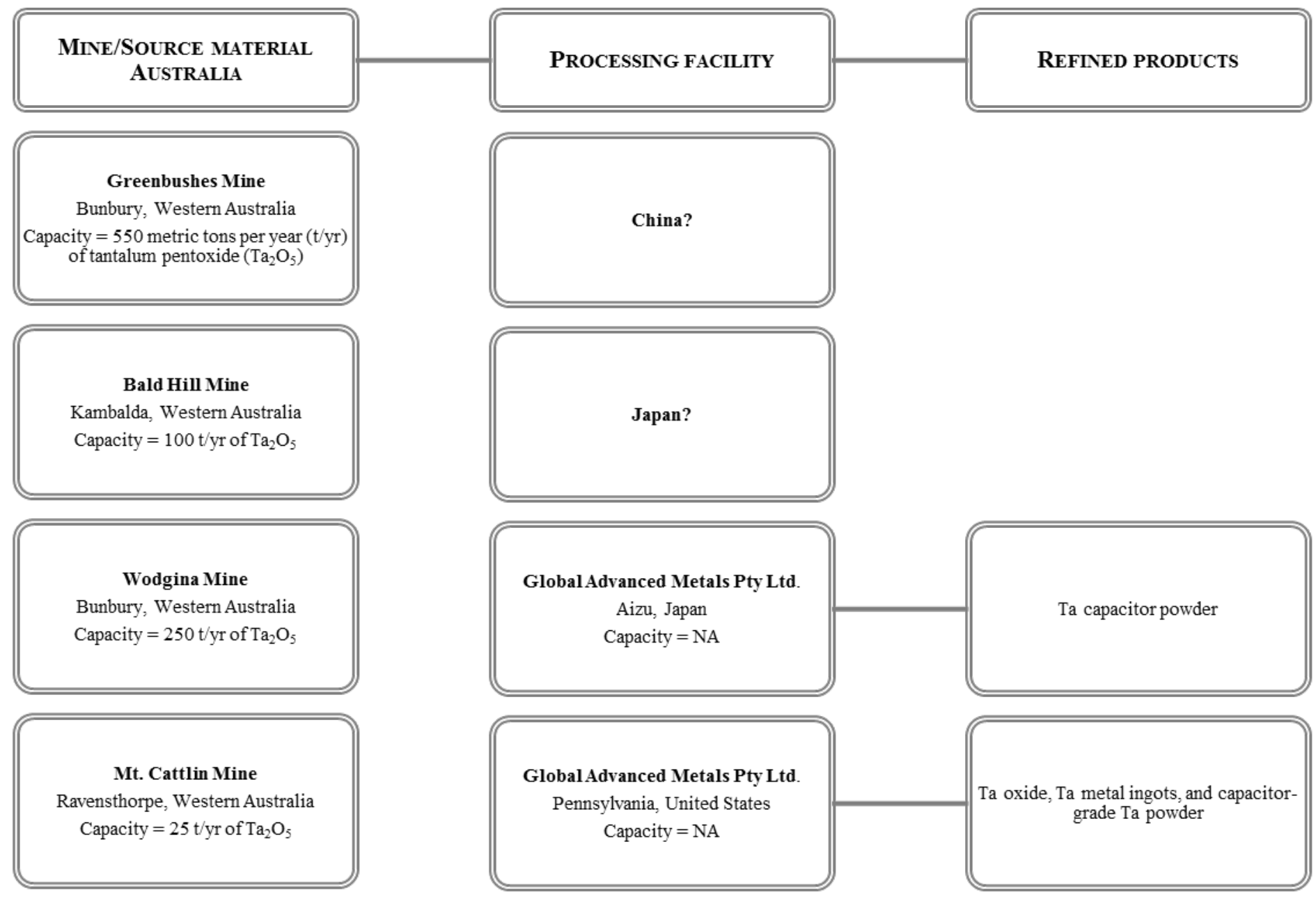

Figure 6. Chart showing the relationship of selected tantalum ( $\mathrm{Ta}$ ) mines (or source materials) and processing facilities and their refined products for mines or deposits located in A, Australia; B, Brazil; C, Burundi; D, Canada; E, China; F, Democratic Republic of the Congo [Congo (Kinshasa)]; G, Egypt; H, Ethiopia; I, Mozambique; J, Thailand; K, Russia; and L, Rwanda. A question mark after the entry indicates a probable location. Abbreviations for compounds and other terms are defined at first use in the figure. For Burundi, * indicates combined capacity. For Thailand, the Ta production capacity was estimated based on tin slag smelting operations in the country. 


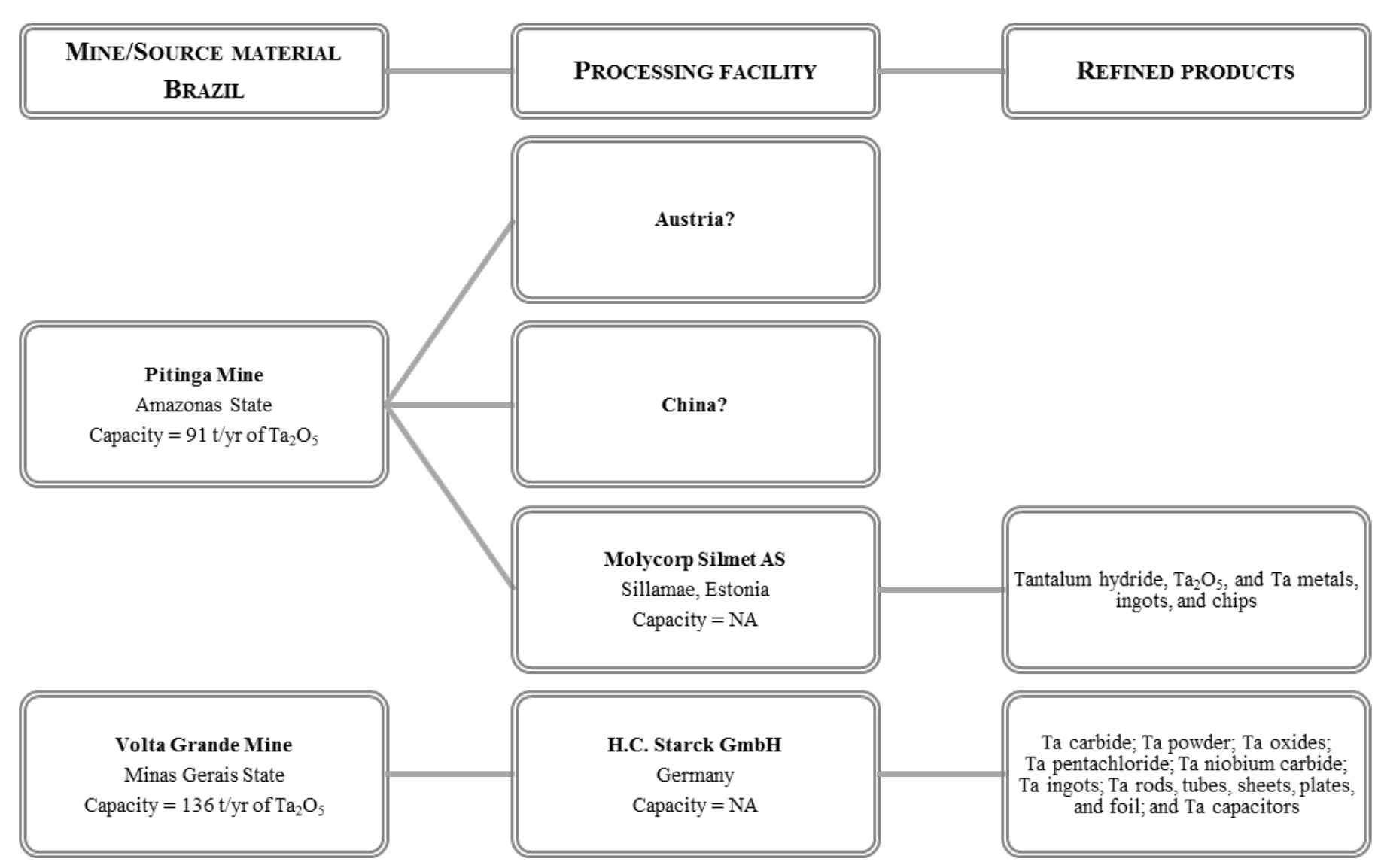

Figure 6.-Continued 


MINE/SOURCE MATERIAL
BURUNDI
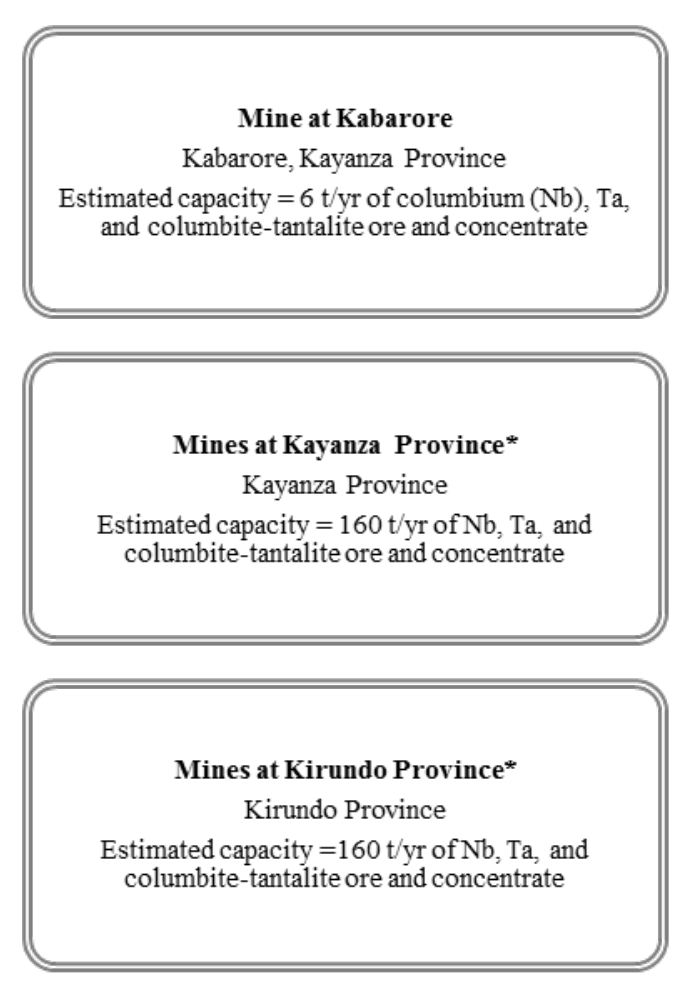

\section{Mines at Ngozi Province*}

Ngozi Province

Estimated capacity $=160 \mathrm{t} / \mathrm{yr}$ of $\mathrm{Nb}, \mathrm{Ta}$, and columbite-tantalite ore and concentrate

Figure 6.—Continued 
D

Mine/SOURCE MATERIAL
Tanco Mine
Manitoba
Capacity $=80 \mathrm{t} / \mathrm{yr}$ of $\mathrm{Ta}_{2} \mathrm{O}_{5}$

$E$

$\begin{gathered}\text { MiNe/SouRCE MATERIAL } \\ \text { CHINA }\end{gathered}$
$\begin{gathered}\text { Yichun Tantalum \& Niobium Mine } \\ \text { Mine 414) } \\ \text { Yichun, Jiangxi Province }\end{gathered}$
$\begin{gathered}\text { Nanping Mine } \\ \text { Nanping, Fujian Province }\end{gathered}$
Conghua Mine
Guangdong Province

\begin{tabular}{|c|c|}
\hline PROCESSING FACILITY & REFINED PRODUCTS \\
\hline $\begin{array}{l}\text { Ningxia Non-Ferrous Metal Smeltery } \\
\text { Shizuishan City, Ningxia Province } \\
\text { Capacity = NA }\end{array}$ & $\begin{array}{l}\text { Estimated production }=300 \mathrm{t} / \mathrm{yr} \text { of Ta powder, } \\
120 \mathrm{t} / \mathrm{yr} \text { of Ta wire, } 30 \mathrm{t} / \mathrm{yr} \text { of Ta oxides, } \\
25 \mathrm{t} / \mathrm{yr} \text { of Ta metal, and } 6 \mathrm{t} / \mathrm{yr} \text { of Ta tube }\end{array}$ \\
\hline $\begin{array}{l}\text { King-Tan Industry Co. Ltd. } \\
\text { Yifeng, Jiangxi Province }\end{array}$ & $\begin{array}{c}\text { Estimated production }=350 \mathrm{t} / \mathrm{yr} \text { of Ta oxides, } \\
300 \mathrm{t} \text { /yr of potassium flourtantalite, } \\
90 \mathrm{t} \text { of Ta powder, and } 30 \mathrm{t} / \mathrm{yr} \text { of carbides }\end{array}$ \\
\hline $\begin{array}{c}\text { Conghua Tantalum and Niobium Smelter } \\
\text { Conghua, Guangdong Province }\end{array}$ & $\begin{array}{c}\text { Estimated production }=50 \mathrm{t} / \mathrm{yr} \text { of Ta powder and } \\
70 \mathrm{t} / \mathrm{yr} \text { of Ta oxides }\end{array}$ \\
\hline $\begin{array}{l}\text { Jiujiang Tanbre's Smelter } \\
\text { Jiangxi Province }\end{array}$ & $\begin{array}{c}\text { Estimated production }=50 \mathrm{t} / \mathrm{yr} \text { of Ta metal and } \\
100 \mathrm{t} / \mathrm{yr} \text { of Ta oxides }\end{array}$ \\
\hline
\end{tabular}

Figure 6.-Continued 


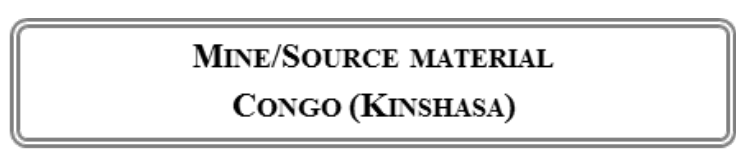

Bibatama Mine

Bibatama in Nord-Kivu Province

Capacity $=120 \mathrm{t} / \mathrm{yr}$ of $\mathrm{Nb}$ and $\mathrm{Ta}$ concentrate

Lueshe Mine
North Kivu Province
Capacity $=1,440$ t/yr of pyrochlore

Mines at Kalemie Territory

Kalemie, Katanga Province

Estimated capacity $=130 \mathrm{t} / \mathrm{yr}$ of columbite-tantalite

Mines at Nyunzu Territory

NuNyunzu, Katanga Province

Estimated capacity $=130 \mathrm{t} / \mathrm{yr}$ of columbite-tantalite

Mines at Maniem

Maniema, Nord-Kivu Province

Capacity $=$ NA

Mines at Manono Territory

Manono, Katanga Province

Estimated capacity $=100 \mathrm{t} / \mathrm{yr}$ of columbite-tantalite

Mines at Nord-Kivu

Nord-Kivu Province

Capacity $=$ NA

Mines at Sud-Kivu

Sud-Kivu Province

Capacity $=$ NA

Figure 6. - Continued 
G

MINE/SOURCE MATERIAL
EGYPT

Abu Dabbab Deposit

Expected initial production of $420 \mathrm{t} / \mathrm{yr}$ of $\mathrm{Ta}_{2} \mathrm{O}_{5}$ or $320 \mathrm{t} / \mathrm{yr}$ of $\mathrm{Ta}$

\section{H.C. Starck GmbH}

Germany

Capacity $=$ NA
Ta carbide; Ta powder; Ta oxides;

Ta pentachloride; Ta niobium carbide; Ta ingots; Ta rods, tubes, sheets, plates, and foil; and Ta capacitors
$H$
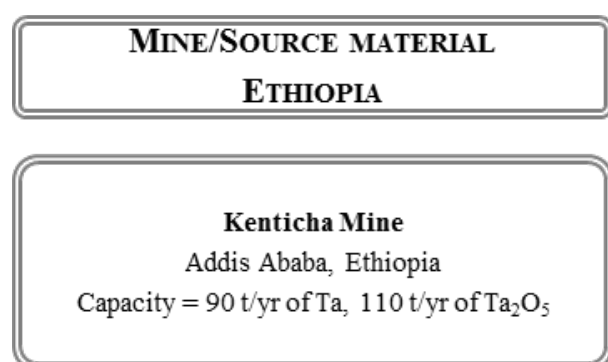

\section{Processing FaCILITY}

H.C. Starck GmbH

Germany

Capacity $=$ NA

\section{REFINED PRODUCTS}

Ta carbide; Ta powder; Ta oxides;

a pentachloride; Ta niobium carbide; Ta ingots

Ta rods, tubes, sheets, plates, and foil; and Ta capacitors

Figure 6.-Continued 


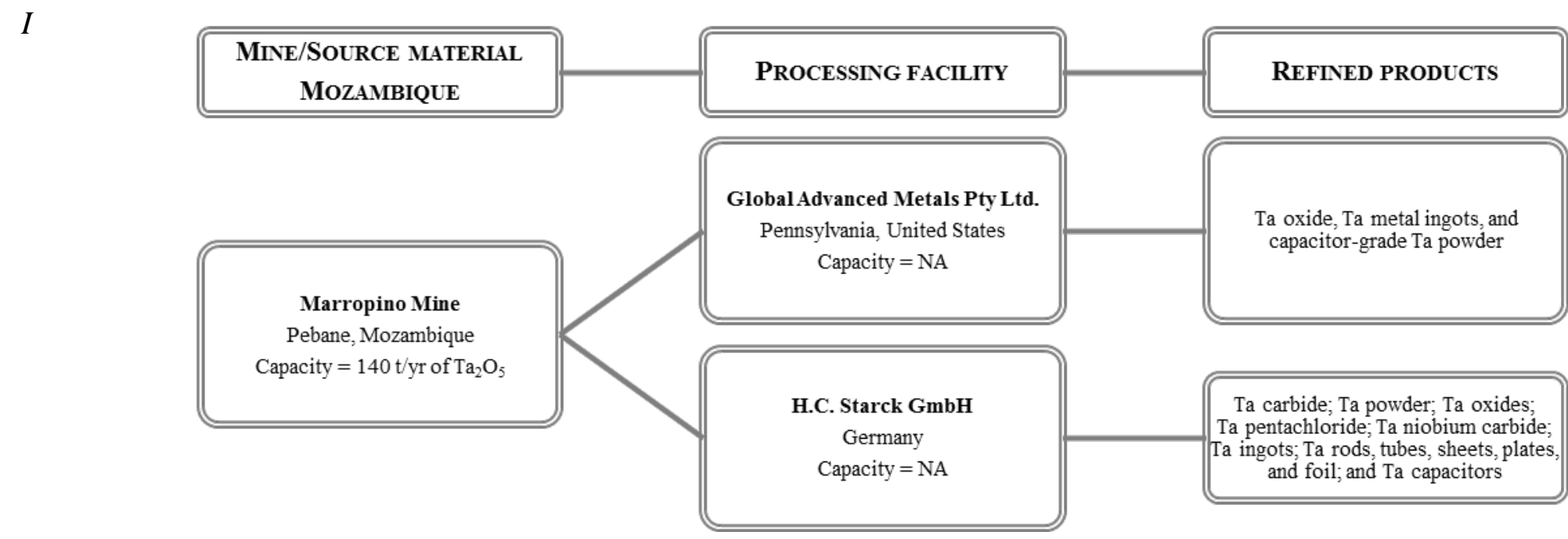

$J$

MiNe/SOURCE MATERIAL
Thailand Smelting and Refining Co.
Ta-bearing tin slag

Figure 6. - Continued 
K

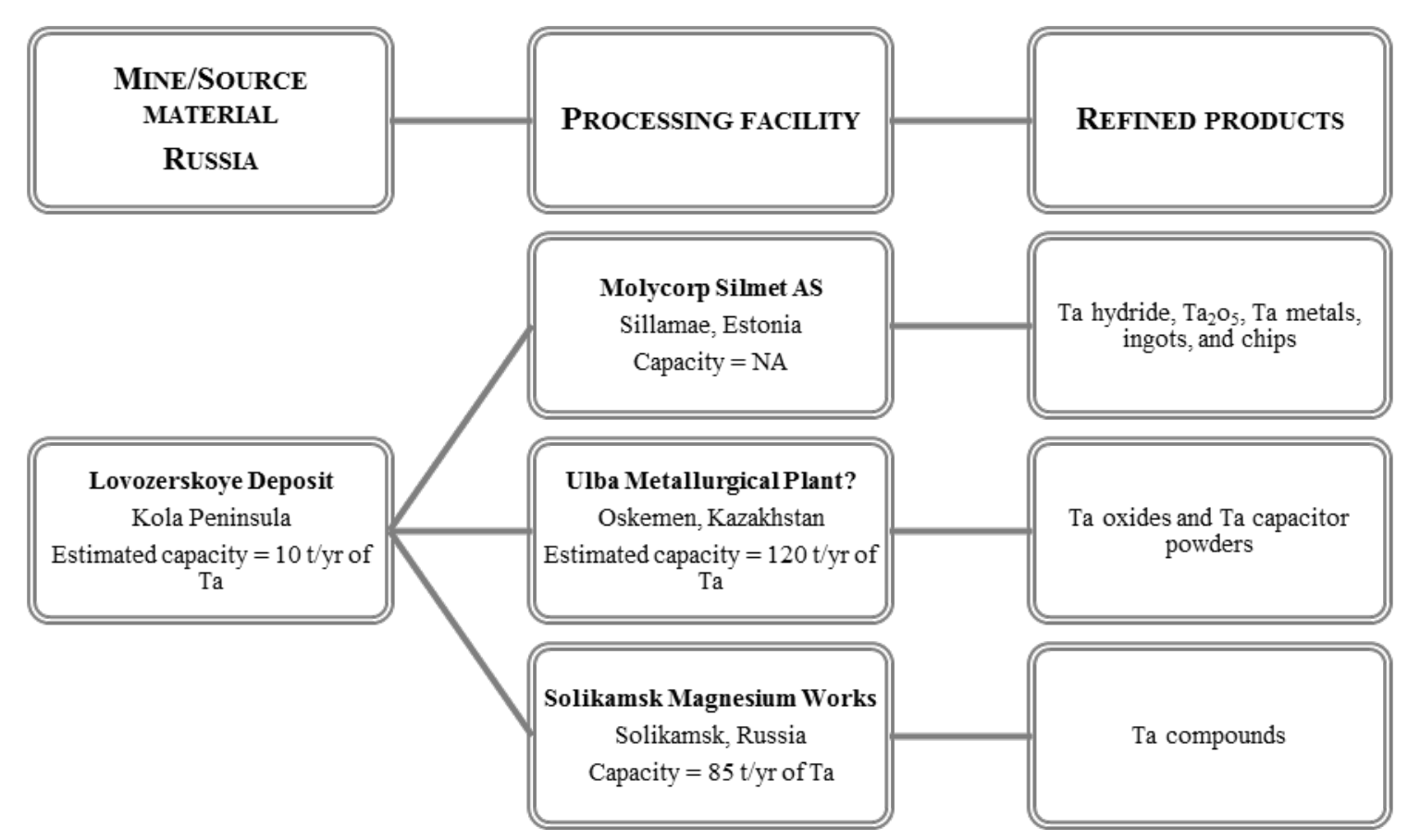

Figure 6.-Continued 


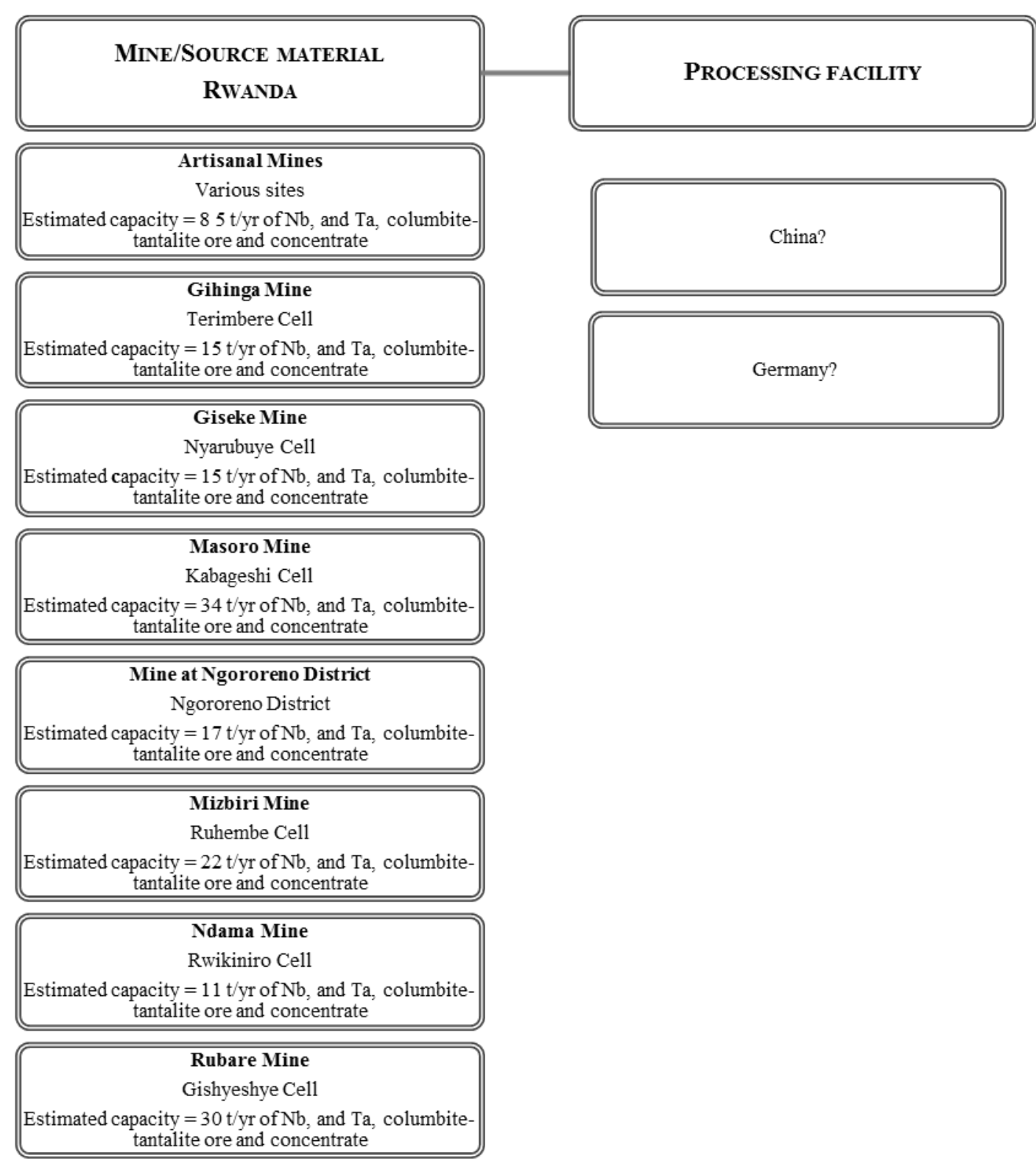

Figure 6.-Continued 

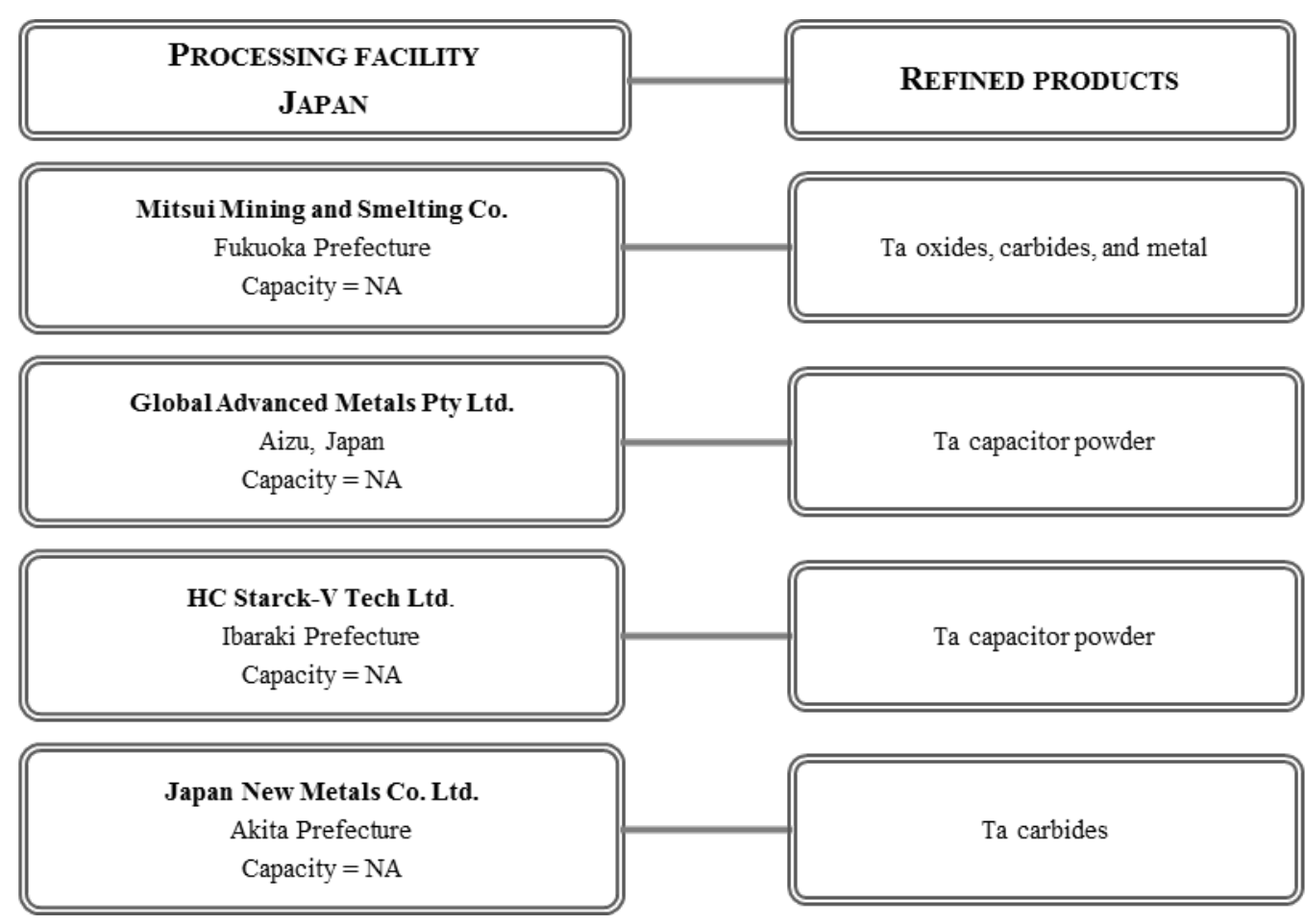

Figure 7. Chart showing tantalum (Ta) refineries in Japan and their products. 


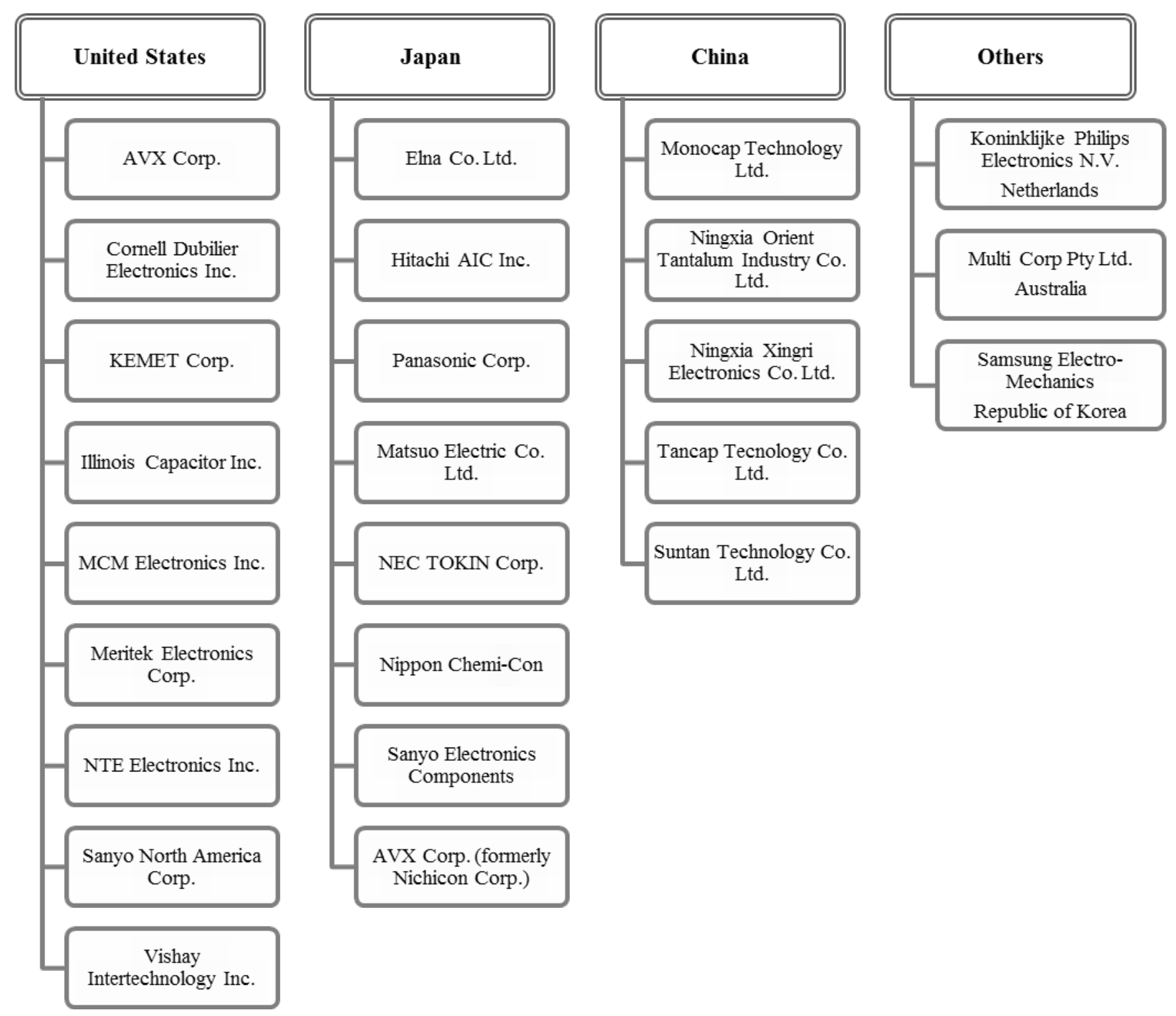

Figure 8. Chart showing selected tantalum capacitor manufacturers. 
Table 1. Significant tantalum mines.

[Mine locations are shown on the map in figure 3. --, not applicable or no data; A, active; CM, care and maintenance; e, estimated; GL, general location; km, kilometer; M, mine; NA, not available; S, surface/open pit; SL, specific location; SU, surface/open pit and underground; $\mathrm{Ta}_{2} \mathrm{O}_{5}$, tantalum pentoxide; U, underground. Data are from U.S. Geological Survey Minerals Yearbook 2011, vol. III (http://minerals.usgs.gov/minerals/)]

\begin{tabular}{|c|c|c|c|c|c|c|c|c|c|c|c|c|c|}
\hline ID & Year & $\begin{array}{l}\text { Specific } \\
\text { mineral } \\
\text { commodity } \\
\text { and (or) } \\
\text { product }\end{array}$ & Country & $\begin{array}{l}\text { Location } \\
\text { description }\end{array}$ & Location name & $\begin{array}{l}\text { Facility } \\
\text { type }\end{array}$ & $\begin{array}{l}\text { Mining } \\
\text { method }\end{array}$ & Ownership & $\begin{array}{l}\text { Annual capacity } \\
\text { (metric tons) }\end{array}$ & Status & $\begin{array}{l}\text { Latitude } \\
\text { (decimal } \\
\text { degrees) }\end{array}$ & $\begin{array}{l}\text { Longitude } \\
\text { (decimal } \\
\text { degrees) }\end{array}$ & $\begin{array}{c}\text { Locational } \\
\text { accuracy }\end{array}$ \\
\hline 1 & 2011 & $\begin{array}{l}\text { Tantalum, } \\
\text { tantalite, } \\
\mathrm{Ta}_{2} \mathrm{O}_{5}\end{array}$ & Australia & $\begin{array}{l}60 \mathrm{~km} \\
\text { southeast of } \\
\text { Kambalda, } \\
\text { Western } \\
\text { Australia }\end{array}$ & $\begin{array}{l}\text { Bald Hill tantalite } \\
\text { mine }\end{array}$ & $\mathrm{M}$ & SU & Altura Mining Ltd.,100\% & $100 \mathrm{Ta}_{2} \mathrm{O}_{5}$ & $\mathrm{CM}$ & -31.672 & 121.894 & SL \\
\hline 2 & 2011 & $\begin{array}{l}\text { Tantalum, } \\
\text { tantalite, } \\
\mathrm{Ta}_{2} \mathrm{O}_{5}\end{array}$ & Australia & $\begin{array}{l}250 \mathrm{~km} \text { from } \\
\text { Perth }\end{array}$ & $\begin{array}{l}\text { Greenbushes open } \\
\text { pit/underground } \\
\text { tantalite-spodumene } \\
\text { mine }\end{array}$ & M & SU & $\begin{array}{l}\text { Global Advanced Metals } \\
\text { Pty Ltd., 80\% and Traxys } \\
\text { Tantalum LP (Traxys } \\
\text { Group), 20\% }\end{array}$ & $550 \mathrm{Ta}_{2} \mathrm{O}_{5}$ & A & -33.857 & 116.051 & SL \\
\hline 3 & 2012 & $\begin{array}{l}\text { Tantalum, } \\
\text { tantalite, } \\
\mathrm{Ta}_{2} \mathrm{O}_{5}\end{array}$ & Australia & $\begin{array}{l}2 \mathrm{~km} \text { north of } \\
\text { Ravensthorpe }\end{array}$ & Mt. Cattlin Mine & M & S & Galaxy Resources Ltd. & $25 \mathrm{Ta}_{2} \mathrm{O}_{5}$ & A & -33.582 & 120.048 & GL \\
\hline 4 & 2011 & $\begin{array}{l}\text { Tantalum, } \\
\text { tantalite, } \\
\mathrm{Ta}_{2} \mathrm{O}_{5}\end{array}$ & Australia & $\begin{array}{l}100 \mathrm{~km} \\
\text { southeast of } \\
\text { Port Hedland }\end{array}$ & $\begin{array}{l}\text { Wodgina open pit } \\
\text { tantalite mine }\end{array}$ & M & SU & $\begin{array}{l}\text { Global Advanced Metals } \\
\text { Pty Ltd., 80\%, and Traxys } \\
\text { Tantalum LP (Traxys } \\
\text { Group), 20\% }\end{array}$ & $250 \mathrm{Ta}_{2} \mathrm{O}_{5}$ & $\mathrm{CM}$ & -21.184 & 118.671 & SL \\
\hline 5 & 2011 & $\begin{array}{l}\text { Tantalum, } \\
\text { concentrate }\end{array}$ & Brazil & $\begin{array}{l}\text { Fluminense } \\
\text { Mine, Minas } \\
\text { Gerais State }\end{array}$ & $\begin{array}{l}\text { Fluminense Mine } \\
\text { (Volta Grande Mine) }\end{array}$ & M & S & $\begin{array}{l}\text { Companhia Industrial } \\
\text { Fluminense (AMG } \\
\text { Advanced Metallurgical } \\
\text { Group N.V.) }\end{array}$ & 25 concentrate & A & -21.084 & -44.583 & SL \\
\hline 6 & 2011 & $\begin{array}{l}\text { Tantalum, } \\
\text { concentrate }\end{array}$ & Brazil & $\begin{array}{l}\text { Pitinga Mine, } \\
\text { Amazonas } \\
\text { State }\end{array}$ & The Pitinga Mine & M & S & $\begin{array}{l}\text { Mineração Taboca S.A. } \\
\text { (private, 100\%) }\end{array}$ & 180 concentrate & A & -0.784 & -60.079 & SL \\
\hline 7 & 2012 & $\begin{array}{l}\text { Niobium } \\
\text { (columbium) } \\
\text { and tantalum, } \\
\text { columbite- } \\
\text { tantalite, ore } \\
\text { and } \\
\text { concentrate }\end{array}$ & Burundi & $\begin{array}{l}\text { Kabarore, } \\
\text { Kayanza } \\
\text { Province }\end{array}$ & Mine at Kabarore & M & -- & $\begin{array}{l}\text { Comptoir Minier des } \\
\text { Exploitations du Burundi } \\
\text { S.A. (COMEBU) }\end{array}$ & $6^{\mathrm{e}}$ & A & -2.824 & 29.581 & GL \\
\hline
\end{tabular}


Table 1. Significant tantalum mines.-Continued

[Mine locations are shown on the map in figure 3. --, not applicable or no data; A, active; CM, care and maintenance; e, estimated; GL, general location;

km, kilometer; M, mine; NA, not available; S, surface/open pit; SL, specific location; SU, surface/open pit and underground; Ta $\mathrm{O}_{5}$, tantalum pentoxide;

U, underground. Data are from U.S. Geological Survey Minerals Yearbook 2011, vol. III (http://minerals.usgs.gov/minerals/)]

\begin{tabular}{|c|c|c|c|c|c|c|c|c|c|c|c|c|c|}
\hline ID & Year & $\begin{array}{c}\text { Specific } \\
\text { mineral } \\
\text { commodity } \\
\text { and (or) } \\
\text { product }\end{array}$ & Country & $\begin{array}{l}\text { Location } \\
\text { description }\end{array}$ & Location name & $\begin{array}{l}\text { Facility } \\
\text { type }\end{array}$ & $\begin{array}{l}\text { Mining } \\
\text { method }\end{array}$ & Ownership & $\begin{array}{l}\text { Annual capacity } \\
\text { (metric tons) }\end{array}$ & Status & $\begin{array}{l}\text { Latitude } \\
\text { (decimal } \\
\text { degrees) }\end{array}$ & $\begin{array}{l}\text { Longitude } \\
\text { (decimal } \\
\text { degrees) }\end{array}$ & $\begin{array}{l}\text { Locational } \\
\text { accuracy }\end{array}$ \\
\hline 8 & 2012 & $\begin{array}{l}\text { Niobium } \\
\text { (columbium) } \\
\text { and tantalum, } \\
\text { columbite- } \\
\text { tantalite, ore } \\
\text { and } \\
\text { concentrate }\end{array}$ & Burundi & $\begin{array}{l}\text { Kayanza } \\
\text { Province }\end{array}$ & $\begin{array}{l}\text { Mines at Kayanza } \\
\text { Province }\end{array}$ & $\mathrm{M}$ & -- & Artisanal miners & $160^{\mathrm{e}, 1}$ & $\mathrm{~A}$ & -3.010 & 29.656 & GL \\
\hline 9 & 2012 & $\begin{array}{l}\text { Niobium } \\
\text { (columbium) } \\
\text { and tantalum, } \\
\text { columbite- } \\
\text { tantalite, ore } \\
\text { and } \\
\text { concentrate }\end{array}$ & Burundi & $\begin{array}{l}\text { Kirundo } \\
\text { Province }\end{array}$ & $\begin{array}{l}\text { Mines at Kirundo } \\
\text { Province }\end{array}$ & M & -- & Artisanal miners & $160^{\mathrm{e}, 1}$ & A & -2.504 & 30.223 & GL \\
\hline 10 & 2012 & $\begin{array}{l}\text { Niobium } \\
\text { (columbium) } \\
\text { and tantalum, } \\
\text { columbite- } \\
\text { tantalite, ore } \\
\text { and } \\
\text { concentrate }\end{array}$ & Burundi & Ngozi Province & $\begin{array}{l}\text { Mines at Ngozi } \\
\text { Province }\end{array}$ & M & -- & Artisanal miners & $160^{\mathrm{e}, 1}$ & A & -2.918 & 29.837 & GL \\
\hline 11 & 2011 & $\begin{array}{l}\text { Tantalum, } \\
\text { tantalite, } \\
\mathrm{Ta}_{2} \mathrm{O}_{5}\end{array}$ & Canada & $\begin{array}{l}\text { Bernic Lake, } \\
\text { Manitoba }\end{array}$ & Tanco Mine & M & $\mathrm{S}$ & Cabot Corp., 100\% & $80 \mathrm{Ta}_{2} \mathrm{O}_{5}$ & $\mathrm{CM}$ & 50.433 & -95.450 & SL \\
\hline 12 & 2012 & Tantalum & China & $\begin{array}{l}\text { Nanping, } \\
\text { Fujian } \\
\text { Province }\end{array}$ & Xikeng Mine & $\mathrm{M}$ & $\mathrm{U}$ & -- & NA & A & 26.600 & 118.042 & GL \\
\hline 13 & 2012 & Tantalum & China & $\begin{array}{l}\text { Yichun, } \\
\text { Jiangxi } \\
\text { Province }\end{array}$ & $\begin{array}{l}\text { Yichun Tantalum \& } \\
\text { Niobium Mine }\end{array}$ & M & $\mathrm{S}$ & $\begin{array}{l}\text { China Minmetals Corp., } \\
\text { Jiangxi Rare Earth Metal } \\
\text { and Rare Metals Tungsten } \\
\text { Group Co. Ltd. }\end{array}$ & NA & A & 27.649 & 114.518 & GL \\
\hline
\end{tabular}


Table 1. Significant tantalum mines.-Continued

[Mine locations are shown on the map in figure 3. --, not applicable or no data; A, active; CM, care and maintenance; e, estimated; GL, general location; km, kilometer; M, mine; NA, not available; S, surface/open pit; SL, specific location; SU, surface/open pit and underground; Ta $\mathrm{O}_{5}$, tantalum pentoxide; U, underground. Data are from U.S. Geological Survey Minerals Yearbook 2011, vol. III (http://minerals.usgs.gov/minerals/)]

\begin{tabular}{|c|c|c|c|c|c|c|c|c|c|c|c|c|c|}
\hline ID & Year & $\begin{array}{l}\text { Specific } \\
\text { mineral } \\
\text { commodity } \\
\text { and (or) } \\
\text { product }\end{array}$ & Country & $\begin{array}{l}\text { Location } \\
\text { description }\end{array}$ & Location name & $\begin{array}{l}\text { Facility } \\
\text { type }\end{array}$ & $\begin{array}{l}\text { Mining } \\
\text { method }\end{array}$ & Ownership & $\begin{array}{l}\text { Annual capacity } \\
\text { (metric tons) }\end{array}$ & Status & $\begin{array}{l}\text { Latitude } \\
\text { (decimal } \\
\text { degrees) }\end{array}$ & $\begin{array}{l}\text { Longitude } \\
\text { (decimal } \\
\text { degrees) }\end{array}$ & $\begin{array}{c}\text { Locational } \\
\text { accuracy }\end{array}$ \\
\hline 14 & 2010 & $\begin{array}{l}\text { Niobium } \\
\text { (columbium) } \\
\text { and tantalum }\end{array}$ & $\begin{array}{l}\text { Congo } \\
\text { (Kinshasa) }\end{array}$ & $\begin{array}{l}\text { Bibatama in } \\
\text { Nord-Kivu } \\
\text { Province }\end{array}$ & Bibatama Mine & $\mathrm{M}$ & -- & $\begin{array}{l}\text { Mwangachuchu Hizi } \\
\text { International }\end{array}$ & 120 concentrate & A & -1.579 & 28.891 & GL \\
\hline 15 & 2011 & $\begin{array}{l}\text { Niobium } \\
\text { (columbium) } \\
\text { and tantalum }\end{array}$ & $\begin{array}{l}\text { Congo } \\
\text { (Kinshasa) }\end{array}$ & Lueshe Mine & $\begin{array}{l}\text { Fluminense Mine } \\
\text { (Volta Grande Mine) }\end{array}$ & M & -- & $\begin{array}{l}\text { Société Minière du Kivu } \\
\text { (Simikivu) [GfE Metalle } \\
\text { und Materialien GmbH, } \\
70 \% \text { ) }\end{array}$ & 1,440 pyrochlore & S & -0.987 & 29.141 & SL \\
\hline 16 & 2011 & $\begin{array}{l}\text { Niobium } \\
\text { (columbium) } \\
\text { and tantalum }\end{array}$ & $\begin{array}{l}\text { Congo } \\
\text { (Kinshasa) }\end{array}$ & $\begin{array}{l}\text { Kalemie, } \\
\text { Katanga } \\
\text { Province }\end{array}$ & $\begin{array}{l}\text { Mines at Kalemie } \\
\text { Territory }\end{array}$ & M & -- & $\begin{array}{l}\text { Artisanal miners and } \\
\text { small-scale miners }\end{array}$ & $\begin{array}{l}130^{\mathrm{e}} \text { columbite- } \\
\text { tantalite }^{2}\end{array}$ & A & -5.935 & 29.180 & GL \\
\hline 17 & 2011 & $\begin{array}{l}\text { Niobium } \\
\text { (columbium) } \\
\text { and tantalum }\end{array}$ & $\begin{array}{l}\text { Congo } \\
\text { (Kinshasa) }\end{array}$ & $\begin{array}{l}\text { Nyunzu, } \\
\text { Katanga } \\
\text { Province }\end{array}$ & Mine at Kabarore & M & -- & $\begin{array}{l}\text { Artisanal miners and } \\
\text { small-scale miners }\end{array}$ & $\begin{array}{l}130^{\mathrm{e}} \text { columbite- } \\
\text { tantalite }^{2}\end{array}$ & A & -5.943 & 28.014 & GL \\
\hline 18 & 2011 & $\begin{array}{l}\text { Niobium } \\
\text { (columbium) } \\
\text { and tantalum }\end{array}$ & $\begin{array}{l}\text { Congo } \\
\text { (Kinshasa) }\end{array}$ & $\begin{array}{l}\text { Maniema, } \\
\text { Nord-Kivu } \\
\text { Province }\end{array}$ & Mines at Maniema & M & -- & $\begin{array}{l}\text { Artisanal miners and } \\
\text { small-scale miners }\end{array}$ & -- & A & -3.073 & 26.041 & GL \\
\hline 19 & 2011 & $\begin{array}{l}\text { Niobium } \\
\text { (columbium) } \\
\text { and tantalum }\end{array}$ & $\begin{array}{l}\text { Congo } \\
\text { (Kinshasa) }\end{array}$ & $\begin{array}{l}\text { Manono, } \\
\text { Katanga } \\
\text { Province }\end{array}$ & $\begin{array}{l}\text { Mines at Manono } \\
\text { Territory }\end{array}$ & M & -- & $\begin{array}{l}\text { Artisanal miners and } \\
\text { small-scale miners }\end{array}$ & $\begin{array}{l}100^{\mathrm{e}} \text { columbite- } \\
\text { tantalite }\end{array}$ & A & -7.309 & 27.464 & GL \\
\hline 20 & 2011 & $\begin{array}{l}\text { Niobium } \\
\text { (columbium) } \\
\text { and tantalum }\end{array}$ & $\begin{array}{l}\text { Congo } \\
\text { (Kinshasa) }\end{array}$ & $\begin{array}{l}\text { Nord-Kivu } \\
\text { Province }\end{array}$ & Mines at Nord-Kivu & M & -- & $\begin{array}{l}\text { Artisanal miners and } \\
\text { small-scale miners }\end{array}$ & NA & A & -07.92 & 29.046 & GL \\
\hline 21 & 2011 & $\begin{array}{l}\text { Niobium } \\
\text { (columbium) } \\
\text { and tantalum }\end{array}$ & $\begin{array}{l}\text { Congo } \\
\text { (Kinshasa) }\end{array}$ & $\begin{array}{l}\text { Sud-Kivu } \\
\text { Province }\end{array}$ & Mines at Sud-Kivu & M & -- & $\begin{array}{l}\text { Artisanal miners and } \\
\text { small-scale miners }\end{array}$ & NA & A & -3.085 & 28.354 & GL \\
\hline 22 & 2012 & Tantalum, ore & Ethiopia & $\begin{array}{l}550 \mathrm{~km} \text { south } \\
\text { of Addis } \\
\text { Ababa }\end{array}$ & Kenticha Mine & M & -- & $\begin{array}{l}\text { Elenito Mineral } \\
\text { Development Share Co. }\end{array}$ & $\begin{array}{l}90 \text { tantalum } \\
\text { (current) }\end{array}$ & $\begin{array}{l}\text { A } \\
\text { (Expansion } \\
\text { proposed by } \\
\text { 2017) }\end{array}$ & 5.454 & 39.017 & SL \\
\hline
\end{tabular}


Table 1. Significant tantalum mines.-Continued

[Mine locations are shown on the map in figure 3. --, not applicable or no data; A, active; CM, care and maintenance; e, estimated; GL, general location; km, kilometer; M, mine; NA, not available; S, surface/open pit; SL, specific location; SU, surface/open pit and underground; Ta $\mathrm{O}_{5}$, tantalum pentoxide; U, underground. Data are from U.S. Geological Survey Minerals Yearbook 2011, vol. III (http://minerals.usgs.gov/minerals/)]

\begin{tabular}{|c|c|c|c|c|c|c|c|c|c|c|c|c|c|}
\hline ID & Year & $\begin{array}{l}\text { Specific } \\
\text { mineral } \\
\text { commodity } \\
\text { and (or) } \\
\text { product }\end{array}$ & Country & $\begin{array}{l}\text { Location } \\
\text { description }\end{array}$ & Location name & $\begin{array}{l}\text { Facility } \\
\text { type }\end{array}$ & $\begin{array}{l}\text { Mining } \\
\text { method }\end{array}$ & Ownership & $\begin{array}{l}\text { Annual capacity } \\
\text { (metric tons) }\end{array}$ & Status & $\begin{array}{l}\text { Latitude } \\
\text { (decimal } \\
\text { degrees) }\end{array}$ & $\begin{array}{l}\text { Longitude } \\
\text { (decimal } \\
\text { degrees) }\end{array}$ & $\begin{array}{c}\text { Locational } \\
\text { accuracy }\end{array}$ \\
\hline 23 & 2011 & $\begin{array}{l}\text { Niobium } \\
\text { (columbium) } \\
\text { and tantalum, } \\
\text { columbite- } \\
\text { tantalite, ore } \\
\text { and } \\
\text { concentrate }\end{array}$ & Mozambique & $\begin{array}{l}350 \mathrm{~km} \\
\text { northeast of } \\
\text { Quelimane, } \\
\text { Zambezia } \\
\text { Province }\end{array}$ & Marropino Mine & $\mathrm{M}$ & $\mathrm{S}$ & $\begin{array}{l}\text { Noventa Ltd. (Highland } \\
\text { African Mining Co. Ltd.) }\end{array}$ & $140 \mathrm{Ta}_{2} \mathrm{O}_{5}$ & $\mathrm{~A}$ & -16.515 & 37.907 & SL \\
\hline 24 & 2010 & Tantalum, ore & Russia & $\begin{array}{l}\text { Zabaykalskiy } \\
\text { mining and } \\
\text { beneficiation } \\
\text { complex }\end{array}$ & Etykinskoye deposit & M & -- & -- & $10^{\mathrm{e}, 3}$ & A & 47.560 & 134.720 & GL \\
\hline 25 & 2010 & Tantalum, ore & Russia & $\begin{array}{l}\text { Lovozerskoye } \\
\text { deposit [Kola } \\
\text { Peninsula] }\end{array}$ & $\begin{array}{l}\text { Lovozerskoye } \\
\text { deposit [Kola } \\
\text { Peninsula] }\end{array}$ & M & -- & -- & $10^{\mathrm{e}, 3}$ & A & 67.333 & 37.000 & GL \\
\hline 26 & 2012 & $\begin{array}{l}\text { Niobium } \\
\text { (columbium) } \\
\text { and tantalum, } \\
\text { columbite- } \\
\text { tantalite, ore } \\
\text { and } \\
\text { concentrate }\end{array}$ & Rwanda & Various Sites & Artisanal Mines & M & -- & Artisanal miners & $85^{\mathrm{e}}$ & A & -1.940 & 29.874 & GL \\
\hline 27 & 2012 & $\begin{array}{l}\text { Niobium } \\
\text { (columbium) } \\
\text { and tantalum, } \\
\text { columbite- } \\
\text { tantalite, ore } \\
\text { and } \\
\text { concentrate }\end{array}$ & Rwanda & Terimbere Cell & Gihinga Mine & M & -- & KODUBU & $15^{\mathrm{e}}$ & A & -1.936 & 29.500 & GL \\
\hline
\end{tabular}


Table 1. Significant tantalum mines.-Continued

[Mine locations are shown on the map in figure 3. --, not applicable or no data; A, active; CM, care and maintenance; e, estimated; GL, general location; km, kilometer; M, mine; NA, not available; S, surface/open pit; SL, specific location; SU, surface/open pit and underground; Ta $\mathrm{O}_{5}$, tantalum pentoxide; U, underground. Data are from U.S. Geological Survey Minerals Yearbook 2011, vol. III (http://minerals.usgs.gov/minerals/)]

\begin{tabular}{|c|c|c|c|c|c|c|c|c|c|c|c|c|c|}
\hline ID & Year & $\begin{array}{l}\text { Specific } \\
\text { mineral } \\
\text { commodity } \\
\text { and (or) } \\
\text { product }\end{array}$ & Country & $\begin{array}{l}\text { Location } \\
\text { description }\end{array}$ & Location name & $\begin{array}{l}\text { Facility } \\
\text { type }\end{array}$ & $\begin{array}{l}\text { Mining } \\
\text { method }\end{array}$ & Ownership & $\begin{array}{l}\text { Annual capacity } \\
\text { (metric tons) }\end{array}$ & Status & $\begin{array}{l}\text { Latitude } \\
\text { (decimal } \\
\text { degrees) }\end{array}$ & $\begin{array}{l}\text { Longitude } \\
\text { (decimal } \\
\text { degrees) }\end{array}$ & $\begin{array}{c}\text { Locational } \\
\text { accuracy }\end{array}$ \\
\hline 28 & 2012 & $\begin{array}{l}\text { Niobium } \\
\text { (columbium) } \\
\text { and tantalum, } \\
\text { columbite- } \\
\text { tantalite, ore } \\
\text { and } \\
\text { concentrate }\end{array}$ & Rwanda & $\begin{array}{l}\text { Nyarubuye } \\
\text { Cell }\end{array}$ & Giseke Mine & $\mathrm{M}$ & -- & KUAKA & $15^{\mathrm{e}}$ & A & -2.552 & 29.829 & GL \\
\hline 29 & 2012 & $\begin{array}{l}\text { Niobium } \\
\text { (columbium) } \\
\text { and tantalum, } \\
\text { columbite- } \\
\text { tantalite, ore } \\
\text { and } \\
\text { concentrate }\end{array}$ & Rwanda & Kabageshi Cell & Masoro Mine & M & -- & Ets Munsad Minerals & $34^{e}$ & A & -1.833 & 30.049 & GL \\
\hline 30 & 2012 & $\begin{array}{l}\text { Niobium } \\
\text { (columbium) } \\
\text { and tantalum, } \\
\text { columbite- } \\
\text { tantalite, ore } \\
\text { and } \\
\text { concentrate }\end{array}$ & Rwanda & $\begin{array}{l}\text { Ngororeno } \\
\text { District }\end{array}$ & $\begin{array}{l}\text { Mine at Ngororeno } \\
\text { District }\end{array}$ & M & -- & $\begin{array}{l}\text { Gatumba Mining } \\
\text { Concessions Ltd. (GMC) } \\
\text { (Kivu Gatumba } 36 \\
\text { Resources Ltd., 51\%, and } \\
\text { Government, 49\%) }\end{array}$ & $17^{\mathrm{e}}$ & A & -1.651 & 29.871 & GL \\
\hline 31 & 2012 & $\begin{array}{l}\text { Niobium } \\
\text { (columbium) } \\
\text { and tantalum, } \\
\text { columbite- } \\
\text { tantalite, ore } \\
\text { and } \\
\text { concentrate }\end{array}$ & Rwanda & Ruhembe Cell & Mizbiri Mine & M & -- & EPROCOMI & $22^{\mathrm{e}}$ & A & -1.651 & 29.871 & GL \\
\hline
\end{tabular}


Table 1. Significant tantalum mines.-Continued

[Mine locations are shown on the map in figure 3. --, not applicable or no data; A, active; CM, care and maintenance; e, estimated; GL, general location; km, kilometer; M, mine; NA, not available; S, surface/open pit; SL, specific location; SU, surface/open pit and underground; Ta $\mathrm{O}_{5}$, tantalum pentoxide; U, underground. Data are from U.S. Geological Survey Minerals Yearbook 2011, vol. III (http://minerals.usgs.gov/minerals/)]

\begin{tabular}{|c|c|c|c|c|c|c|c|c|c|c|c|c|c|}
\hline ID & Year & $\begin{array}{l}\text { Specific } \\
\text { mineral } \\
\text { commodity } \\
\text { and (or) } \\
\text { product }\end{array}$ & Country & $\begin{array}{l}\text { Location } \\
\text { description }\end{array}$ & Location name & $\begin{array}{l}\text { Facility } \\
\text { type }\end{array}$ & $\begin{array}{l}\text { Mining } \\
\text { method }\end{array}$ & Ownership & $\begin{array}{c}\text { Annual capacity } \\
\text { (metric tons) }\end{array}$ & Status & $\begin{array}{l}\text { Latitude } \\
\text { (decimal } \\
\text { degrees) }\end{array}$ & $\begin{array}{l}\text { Longitude } \\
\text { (decimal } \\
\text { degrees) }\end{array}$ & $\begin{array}{c}\text { Locational } \\
\text { accuracy }\end{array}$ \\
\hline 32 & 2012 & $\begin{array}{l}\text { Niobium } \\
\text { (columbium) } \\
\text { and tantalum, } \\
\text { columbite- } \\
\text { tantalite, ore } \\
\text { and } \\
\text { concentrate }\end{array}$ & Rwanda & Rwikiniro Cell & Ndama Mine & $\mathrm{M}$ & -- & Vision Mining Co. & $11^{\mathrm{e}}$ & A & -1.387 & 30.473 & GL \\
\hline 33 & 2012 & $\begin{array}{l}\text { Niobium } \\
\text { (columbium) } \\
\text { and tantalum, } \\
\text { columbite- } \\
\text { tantalite, ore } \\
\text { and } \\
\text { concentrate }\end{array}$ & Rwanda & $\begin{array}{l}\text { Gishyeshye } \\
\text { Cell }\end{array}$ & Rubare Mine & M & -- & Ets Kalinda & $30^{\mathrm{e}}$ & A & -1.600 & 29.463 & GL \\
\hline
\end{tabular}

${ }^{1}$ Combined capacity of facilities corresponding to ID numbers 8 through 10 in this table.

${ }^{2}$ Combined capacity of facilities corresponding to ID numbers 16 and 17 in this table.

${ }^{3}$ Combined capacity of facilities corresponding to ID numbers 24 and 25 in this table. 
Table 2. Prospective tantalum deposits and producers in the world.

[Producer locations are shown on the map in figure 4. --, not applicable or no data; A, active; CM, care and maintenance; D, deposit; e, estimated; GL, general location; km, kilometer; $\mathrm{M}$, mine; NA, not available; $\mathrm{P}_{2} \mathrm{O}_{5}$; phosphorus pentoxide; $\mathrm{REO}$, rare-earth oxide; $\mathrm{S}$, surface/open pit;

SL, specific location; SU, surface/open pit and underground; $\mathrm{Ta}_{2} \mathrm{O}_{5}$, tantalum pentoxide; U, underground; UD, under development. Data are from U.S. Geological Survey Minerals Yearbook 2011, vol. III (http://minerals.usgs.gov/minerals/)]

\begin{tabular}{|c|c|c|c|c|c|c|c|c|c|c|c|c|c|c|}
\hline ID & $\begin{array}{l}\text { Specific } \\
\text { mineral } \\
\text { commodity } \\
\text { and (or) } \\
\text { product }\end{array}$ & Country & $\begin{array}{l}\text { Location } \\
\text { description }\end{array}$ & Location name & $\begin{array}{l}\text { Facility } \\
\text { type }\end{array}$ & $\begin{array}{l}\text { Mining } \\
\text { method }\end{array}$ & Ownership & $\begin{array}{c}\text { Tonnage } \\
\text { (million metric } \\
\text { tons) }\end{array}$ & $\begin{array}{c}\text { Grade } \\
\text { (parts per } \\
\text { million) }\end{array}$ & $\begin{array}{l}\text { Annual } \\
\text { capacity } \\
\text { (metric } \\
\text { tons) }\end{array}$ & Status & $\begin{array}{l}\text { Latitude } \\
\text { (decimal } \\
\text { degrees) }\end{array}$ & $\begin{array}{l}\text { Longitude } \\
\text { (decimal } \\
\text { degrees) }\end{array}$ & $\begin{array}{l}\text { Locational } \\
\text { accuracy }\end{array}$ \\
\hline 1 & Tantalum & Australia & $\begin{array}{l}35 \text { km south of } \\
\text { Laverton, } \\
\text { Western } \\
\text { Australia }\end{array}$ & Mount Weld & $\mathrm{D}$ & S & $\begin{array}{l}\text { Lynas Corp. } \\
\text { Ltd. }\end{array}$ & -- & -- & -- & UD & -28.897 & 122.384 & SL \\
\hline 2 & Tantalum & Australia & $\begin{array}{l}\text { Dubbo, New } \\
\text { South Wales }\end{array}$ & $\begin{array}{l}\text { Dubbo Zirconia } \\
\text { Project }\end{array}$ & $\mathrm{D}$ & S & $\begin{array}{l}\text { Australian } \\
\text { Zirconia Ltd., } \\
\text { 100\% (Alkane } \\
\text { Resources } \\
\text { Ltd.) }\end{array}$ & 73.2 & $0.03 \mathrm{Ta}_{2} \mathrm{O}_{5}$ & $600 \mathrm{Ta}_{2} \mathrm{O}_{5}$ & A & -32.418 & 148.713 & SL \\
\hline 3 & Tantalum & Australia & $\begin{array}{l}135 \mathrm{~km} \\
\text { northwest of } \\
\text { Alice Springs }\end{array}$ & $\begin{array}{l}\text { Nolans Rare } \\
\text { Earths Project }\end{array}$ & $\mathrm{D}$ & S & $\begin{array}{l}\text { Arafura } \\
\text { Resources } \\
\text { Ltd., } 100 \%\end{array}$ & 47 & $\begin{array}{c}2.6 \% \text { REO, } \\
11 \% \mathrm{P}_{2} \mathrm{O}_{5}\end{array}$ & $200^{\mathrm{e}} \mathrm{Ta}_{2} \mathrm{O}_{5}$ & A & -23.617 & 133.857 & SL \\
\hline 4 & Tantalum & Canada & $\begin{array}{l}100 \mathrm{~km} \\
\text { southeast of } \\
\text { Yellowknife }\end{array}$ & $\begin{array}{l}\text { Nechalacho } \\
\text { Rare-Earth } \\
\text { Element } \\
\text { Deposit }\end{array}$ & $\mathrm{D}$ & $\mathrm{U}$ & $\begin{array}{l}\text { Avalon Rare } \\
\text { Metals Inc., } \\
100 \%\end{array}$ & $\begin{array}{l}14.5 \text { (probable } \\
\text { reserves) }\end{array}$ & $400 \mathrm{Ta}_{2} \mathrm{O}_{5}$ & -- & UD & 62.096 & -112.489 & SL \\
\hline 5 & Tantalum & Canada & $\begin{array}{l}10 \mathrm{~km} \text { north of } \\
\text { Blue River }\end{array}$ & $\begin{array}{l}\text { Blue River } \\
\text { Tantalum- } \\
\text { Niobium } \\
\text { Project, Upper } \\
\text { Fir Deposit }\end{array}$ & $\mathrm{D}$ & $\mathrm{U}$ & $\begin{array}{l}\text { Commerce } \\
\text { Resource } \\
\text { Corp., 100\% }\end{array}$ & $\begin{array}{l}36.35 \text { (indicated)/ } \\
6.40 \mathrm{Mt} \\
\text { (inferred) }\end{array}$ & $\begin{array}{r}195 \mathrm{Ta}_{2} \mathrm{O}_{5} / \\
199 \mathrm{Ta}_{2} \mathrm{O}_{5}\end{array}$ & $275^{\mathrm{e}} \mathrm{Ta}_{2} \mathrm{O}_{5}$ & UD & 52.232 & -119.169 & SL \\
\hline 6 & Tantalum & Canada & $\begin{array}{l}\text { Crevier } \\
\text { Township, Lac } \\
\text { Saint-Jean } \\
\text { Region }\end{array}$ & Crevier Deposit & $\mathrm{D}$ & SU & $\begin{array}{l}\text { MDN Inc., } \\
72.5 \% \text {, and } \\
\text { IAMGOLD, } \\
27.5 \%\end{array}$ & $\begin{array}{c}25.4 \text { (measured } \\
\text { and indicated)/ } \\
15.4 \text { (inferred) }\end{array}$ & $\begin{array}{l}234 \mathrm{Ta}_{2} \mathrm{O}_{5} \\
\quad / 252 \mathrm{Ta}_{2} \mathrm{O}_{5}\end{array}$ & $100^{\mathrm{e}} \mathrm{Ta}_{2} \mathrm{O}_{5}$ & UD & 49.500 & -72.816 & SL \\
\hline 7 & Tantalum & China & $\begin{array}{l}\text { Dajishan, } \\
\text { Jiangxi } \\
\text { Province }\end{array}$ & $\begin{array}{c}\text { Dajishan } \\
\text { Deposit }\end{array}$ & $\mathrm{D}$ & -- & $\begin{array}{l}\text { Lynas Corp. } \\
\text { Ltd. }\end{array}$ & -- & -- & -- & $\mathrm{U}$ & 24.583 & 114.381 & GL \\
\hline
\end{tabular}


Table 2. Prospective tantalum deposits and producers in the world.-Continued

[Producer locations are shown on the map in figure 4. --, not applicable or no data; A, active; CM, care and maintenance; D, deposit; e, estimated; GL, general location; km, kilometer; $\mathrm{M}$, mine; $\mathrm{NA}$, not available; $\mathrm{P}_{2} \mathrm{O}_{5}$; phosphorus pentoxide; REO, rare-earth oxide; $\mathrm{S}$, surface/open pit;

$\mathrm{SL}$, specific location; $\mathrm{SU}$, surface/open pit and underground; $\mathrm{Ta}_{2} \mathrm{O}_{5}$, tantalum pentoxide; U, underground; UD, under development. Data are from U.S. Geological Survey Minerals Yearbook 2011, vol. III (http://minerals.usgs.gov/minerals/)]

\begin{tabular}{|c|c|c|c|c|c|c|c|c|c|c|c|c|c|c|}
\hline ID & $\begin{array}{c}\text { Specific } \\
\text { mineral } \\
\text { commodity } \\
\text { and (or) } \\
\text { product }\end{array}$ & Country & $\begin{array}{l}\text { Location } \\
\text { description }\end{array}$ & Location name & $\begin{array}{l}\text { Facility } \\
\text { type }\end{array}$ & $\begin{array}{l}\text { Mining } \\
\text { method }\end{array}$ & Ownership & $\begin{array}{c}\text { Tonnage } \\
\text { (million metric } \\
\text { tons) }\end{array}$ & $\begin{array}{c}\text { Grade } \\
\text { (parts per } \\
\text { million) }\end{array}$ & $\begin{array}{l}\text { Annual } \\
\text { capacity } \\
\text { (metric } \\
\text { tons) }\end{array}$ & Status & $\begin{array}{l}\text { Latitude } \\
\text { (decimal } \\
\text { degrees) }\end{array}$ & $\begin{array}{c}\text { Longitude } \\
\text { (decimal } \\
\text { degrees) }\end{array}$ & $\begin{array}{c}\text { Locational } \\
\text { accuracy }\end{array}$ \\
\hline 8 & Tantalum & China & $\begin{array}{l}\text { Xianghualing, } \\
\text { Hunan } \\
\text { Province }\end{array}$ & $\begin{array}{l}\text { Xianghualing } \\
\text { Deposit }\end{array}$ & $\mathrm{D}$ & -- & -- & -- & -- & -- & $\mathrm{U}$ & 25.433 & 112.533 & GL \\
\hline 9 & Tantalum & China & $\begin{array}{l}\text { Boluo, } \\
\text { Guangdong } \\
\text { Province }\end{array}$ & Boluo Deposit & $\mathrm{D}$ & -- & -- & -- & -- & -- & $\mathrm{U}$ & 23.132 & 113.267 & GL \\
\hline 10 & Tantalum & China & $\begin{array}{l}\text { Limu, Guangxi } \\
\text { Province }\end{array}$ & Limu Deposit & $\mathrm{D}$ & -- & -- & -- & -- & -- & $\mathrm{U}$ & 24.850 & 110.800 & GL \\
\hline 11 & Tantalum & China & $\begin{array}{l}\text { Xiangdong, } \\
\text { Hunan Province }\end{array}$ & $\begin{array}{l}\text { Xiangdong } \\
\text { Deposit }\end{array}$ & $\mathrm{D}$ & -- & -- & -- & -- & -- & $\mathrm{U}$ & 26.492 & 112.911 & GL \\
\hline 12 & Tantalum & Egypt & $\begin{array}{l}16 \mathrm{~km} \text { inland } \\
\text { from the } \\
\text { western shore } \\
\text { of the Red Sea }\end{array}$ & $\begin{array}{l}\text { Abu Dabbab } \\
\text { and Nuweibi } \\
\text { project }\end{array}$ & M & S & $\begin{array}{l}\text { Tantalum } \\
\text { Egypt J.S.C. } \\
\text { (Egyptian } \\
\text { Company for } \\
\text { Mineral } \\
\text { Resources } \\
\text { 50\%, and } \\
\text { Tantalum } \\
\text { International } \\
\text { Pty Ltd., 50\% } \\
\text { (Gippsland } \\
\text { Ltd.) }\end{array}$ & 44.5 & $250 \mathrm{Ta}_{2} \mathrm{O}_{5}$ & $420 \mathrm{Ta}_{2} \mathrm{O}_{5}$ & UD & 49.500 & -72.816 & SL \\
\hline 13 & Tantalum & Malawi & $\begin{array}{l}150 \text { km from } \\
\text { Malawi City, } \\
\text { Lilongwe, } \\
\text { Mzimba } \\
\text { District }\end{array}$ & $\begin{array}{l}\text { Kanyika } \\
\text { Niobium } \\
\text { Project }\end{array}$ & $\mathrm{D}$ & S & $\begin{array}{l}\text { Globe Metals } \\
\text { \& Mining }\end{array}$ & 60 & -- & -- & UD & -12.813 & 33.460 & SL \\
\hline 14 & Tantalum & Mozambique & $\begin{array}{r}\text { Zambezia } \\
\text { Province }\end{array}$ & Morrua Mine & $\mathrm{D}$ & S & $\begin{array}{l}\text { Noventa Ltd. } \\
\text { (Highland } \\
\text { Africa Mining } \\
\text { Co. Ltd.) }\end{array}$ & $\begin{array}{l}4.6 \text { (indicated)/ } \\
3.1 \text { (inferred) }\end{array}$ & -- & -- & $\mathrm{CM}$ & -16.270 & 37.866 & SL \\
\hline
\end{tabular}


Table 2. Prospective tantalum deposits and producers in the world.-Continued

[Producer locations are shown on the map in figure 4. --, not applicable or no data; A, active; CM, care and maintenance; D, deposit; e, estimated; GL, general location; km, kilometer; $\mathrm{M}$, mine; NA, not available; $\mathrm{P}_{2} \mathrm{O}_{5}$; phosphorus pentoxide; $\mathrm{REO}$, rare-earth oxide; $\mathrm{S}$, surface/open pit;

$\mathrm{SL}$, specific location; $\mathrm{SU}$, surface/open pit and underground; $\mathrm{Ta}_{2} \mathrm{O}_{5}$, tantalum pentoxide; U, underground; UD, under development. Data are from U.S. Geological Survey Minerals Yearbook 2011, vol. III (http://minerals.usgs.gov/minerals/)]

\begin{tabular}{|c|c|c|c|c|c|c|c|c|c|c|c|c|c|c|}
\hline ID & $\begin{array}{c}\text { Specific } \\
\text { mineral } \\
\text { commodity } \\
\text { and (or) } \\
\text { product }\end{array}$ & Country & $\begin{array}{l}\text { Location } \\
\text { description }\end{array}$ & Location name & $\begin{array}{c}\text { Facility } \\
\text { type }\end{array}$ & $\begin{array}{l}\text { Mining } \\
\text { method }\end{array}$ & Ownership & $\begin{array}{c}\text { Tonnage } \\
\text { (million metric } \\
\text { tons) }\end{array}$ & $\begin{array}{c}\text { Grade } \\
\text { (parts per } \\
\text { million) }\end{array}$ & $\begin{array}{l}\text { Annual } \\
\text { capacity } \\
\text { (metric } \\
\text { tons) }\end{array}$ & Status & $\begin{array}{l}\text { Latitude } \\
\text { (decimal } \\
\text { degrees) }\end{array}$ & $\begin{array}{l}\text { Longitude } \\
\text { (decimal } \\
\text { degrees) }\end{array}$ & $\begin{array}{c}\text { Locational } \\
\text { accuracy }\end{array}$ \\
\hline 15 & Tantalum & Mozambique & $\begin{array}{r}\text { Zambezia } \\
\text { Province }\end{array}$ & Mutala Mine & $\mathrm{D}$ & $\mathrm{S}$ & $\begin{array}{l}\text { Noventa Ltd. } \\
\text { (Highland } \\
\text { Africa Mining } \\
\text { Co. Ltd.) }\end{array}$ & -- & -- & -- & $\mathrm{CM}$ & -15.930 & 37.912 & SL \\
\hline 16 & Tantalum & Saudi Arabia & Tabuk & $\begin{array}{l}\text { Ghurayyah } \\
\text { Tantalum- } \\
\text { Niobium REE } \\
\text { Project }\end{array}$ & $\mathrm{D}$ & -- & $\begin{array}{l}\text { Tertiary } \\
\text { Minerals plc, } \\
\text { 50\%, AH } \\
\text { Algosaibi } \\
\text { Bros Co., } \\
\text { 25\%, and } \\
\text { Al Nahla } \\
\text { Trading \& } \\
\text { Contracting } \\
\text { Co., 25\% }\end{array}$ & 400 (inferred) & $245 \mathrm{Ta}_{2} \mathrm{O}_{5}$ & $275^{\mathrm{e}} \mathrm{Ta}_{2} \mathrm{O}_{5}$ & S & 28.375 & 36.527 & GL \\
\hline
\end{tabular}


Table 3. Significant tantalum plants (fabricators and refineries).

[Locations of fabricators and refineries are shown on the map in figure 5. --, not applicable or no data; ?, uncertain; A, active; e, estimated; F, fabricator; GL, general location; NA, not available; P, plant; R, refinery; SL, specific location. Data are from U.S. Geological Survey Minerals Yearbook 2011, vol. III (http://minerals.usgs.gov/minerals/)]

\begin{tabular}{|c|c|c|c|c|c|c|c|c|c|c|c|c|}
\hline ID & Year & $\begin{array}{l}\text { Specific mineral } \\
\text { commodity } \\
\text { and (or) } \\
\text { product }\end{array}$ & Country & Location description & Location name & $\begin{array}{l}\text { Facility } \\
\text { type }\end{array}$ & Ownership & $\begin{array}{c}\text { Annual } \\
\text { capacity } \\
\text { (metric tons) }\end{array}$ & Status & $\begin{array}{l}\text { Latitude } \\
\text { (decimal } \\
\text { degrees) }\end{array}$ & $\begin{array}{c}\text { Longitude } \\
\text { (decimal } \\
\text { degrees) }\end{array}$ & $\begin{array}{l}\text { Locational } \\
\text { accuracy }\end{array}$ \\
\hline 1 & 2012 & Tantalum & Austria & Althofen, Carinthia & Treibacher Industrie AG & $\mathrm{P}(\mathrm{F})$ & $\begin{array}{l}\text { Treibacher } \\
\text { Industrie AG }\end{array}$ & -- & A & 46.867 & 14.460 & SL \\
\hline 2 & 2012 & Tantalum & Austria & Liezen & PLANSEE Liezen & $\mathrm{P}(\mathrm{F})$ & $\begin{array}{l}\text { Plansee SE, } \\
100 \%\end{array}$ & -- & A & 47.561 & 14.247 & SL \\
\hline 3 & 2012 & Tantalum & Brazil & $\begin{array}{l}\text { Sao Joao del Rei, } \\
\text { Minas Gerais }\end{array}$ & $\begin{array}{l}\text { Companhia Industrial } \\
\text { Fluminense }\end{array}$ & $\mathrm{P}(\mathrm{R})$ & $\begin{array}{l}\text { Companhia } \\
\text { Industrial } \\
\text { Fluminense } \\
\text { (AMG } \\
\text { Advanced } \\
\text { Metallurgical } \\
\text { Group N.V.) }\end{array}$ & -- & A & -21.084 & -44.583 & SL \\
\hline 4 & 2012 & Tantalum & China & $\begin{array}{l}\text { Ye Jin Road, } \\
\text { Shizuishan City, } \\
\text { Ningxia Province }\end{array}$ & $\begin{array}{l}\text { Ningxia Non-Ferrous } \\
\text { Metal Smelter }\end{array}$ & $\mathrm{P}(\mathrm{R})$ & $\begin{array}{l}\text { Ningxia Non- } \\
\text { ferrous Metal } \\
\text { Smelter }\end{array}$ & $\begin{array}{l}300^{\mathrm{e}} \text { tantalum } \\
\text { powder, } \\
120^{\mathrm{e}} \text { tantalum } \\
\text { wire, } 30^{\mathrm{e}} \text { tantalum } \\
\text { oxide, } \\
25^{\mathrm{e}} \text { tantalum } \\
\text { metal, } 6^{\mathrm{e}} \text { tantalum } \\
\text { tube }\end{array}$ & A & 38.994 & 106.375 & GL \\
\hline 5 & 2012 & Tantalum & China & $\begin{array}{l}\text { Shishi Industrial } \\
\text { Zone, Yifeng, } \\
\text { Jiangxi Province }\end{array}$ & $\begin{array}{l}\text { King-Tan Tantalum } \\
\text { Industry Ltd. }\end{array}$ & $\mathrm{P}(\mathrm{R})$ & $\begin{array}{l}\text { King-Tan } \\
\text { Tantalum } \\
\text { Industry Ltd. }\end{array}$ & $\begin{array}{l}350^{\mathrm{e}} \text { tantalum } \\
\text { powder, } \\
120^{\mathrm{e}} \text { t wire, } \\
30^{\mathrm{e}} \text { t oxide, } \\
25^{\mathrm{e}} \text { tantalum } \\
\text { metal, } 30^{\mathrm{e}} \text { carbide }\end{array}$ & A & 28.256 & 114.777 & GL \\
\hline 6 & 2012 & Tantalum & China & $\begin{array}{l}\text { Conghua, } \\
\text { Guangdong } \\
\text { Province }\end{array}$ & $\begin{array}{l}\text { Conghua Tantalum and } \\
\text { Niobium Smelter }\end{array}$ & $\mathrm{P}(\mathrm{R} ?)$ & $\begin{array}{l}\text { Congua Tantalum } \\
\text { \& Niobium } \\
\text { Smelter }\end{array}$ & $\begin{array}{l}50^{\mathrm{e}} \text { tantalum } \\
\text { powder, } \\
70^{\mathrm{e}} \text { tantalum oxide }\end{array}$ & A & 23.548 & 113.587 & GL \\
\hline 7 & 2012 & Tantalum & China & Jiangxi Province & Jiujiang Tanbre’s Smelter & $\mathrm{P}(\mathrm{R} ?)$ & $\begin{array}{l}\text { Jiangxi Tungsten } \\
\text { Group Limited } \\
\text { Corp. }\end{array}$ & $\begin{array}{l}50^{\mathrm{e}} \text { tantalum metal, } \\
100^{\mathrm{e}} \text { tantalum } \\
\text { oxide }\end{array}$ & A & 29.705 & 116.002 & GL \\
\hline
\end{tabular}


Table 3. Significant tantalum plants (fabricators and refineries).-Continued

[Locations of fabricators and refineries are shown on the map in figure 5. --, not applicable or no data; ?, uncertain; A, active; e, estimated;

F, fabricator; GL, general location; NA, not available; P, plant; R, refinery; SL, specific location. Data are from U.S. Geological Survey Minerals Yearbook 2011, vol. III (http://minerals.usgs.gov/minerals/)]

\begin{tabular}{|c|c|c|c|c|c|c|c|c|c|c|c|c|}
\hline ID & Year & $\begin{array}{l}\text { Specific mineral } \\
\text { commodity } \\
\text { and (or) } \\
\text { product }\end{array}$ & Country & Location description & Location name & $\begin{array}{l}\text { Facility } \\
\text { type }\end{array}$ & Ownership & $\begin{array}{c}\text { Annual } \\
\text { capacity } \\
\text { (metric tons) }\end{array}$ & Status & $\begin{array}{l}\text { Latitude } \\
\text { (decimal } \\
\text { degrees) }\end{array}$ & $\begin{array}{l}\text { Longitude } \\
\text { (decimal } \\
\text { degrees) }\end{array}$ & $\begin{array}{l}\text { Locational } \\
\text { accuracy }\end{array}$ \\
\hline 8 & 2012 & Tantalum & Estonia & Sillamae & Molycorp Silmet AS & $\mathrm{P}(\mathrm{R})$ & $\begin{array}{l}\text { Molycorp Inc., } \\
90 \%\end{array}$ & -- & A & 59.401 & 27.746 & GL \\
\hline 9 & 2012 & Tantalum & Germany & Im Schleek, Goslar & Goslar Plant & $\mathrm{P}(\mathrm{R})$ & $\begin{array}{l}\text { H.C. Starck } \\
\text { GmbH }\end{array}$ & -- & A & 51.909 & 10.474 & SL \\
\hline 10 & 2012 & Tantalum & Germany & $\begin{array}{l}\text { Ferroweg, } \\
\text { Laufenburg }\end{array}$ & Rhina Plant & $\mathrm{P}(\mathrm{R})$ & $\begin{array}{l}\text { H.C. Starck } \\
\text { GmbH }\end{array}$ & -- & A & 47.556 & 8.039 & SL \\
\hline 11 & 2012 & Tantalum & Germany & $\begin{array}{l}\text { Sackinger Strasse, } \\
\text { Laufenburg }\end{array}$ & ENAG Plant & $\mathrm{P}(\mathrm{R})$ & $\begin{array}{l}\text { H.C. Starck } \\
\text { GmbH }\end{array}$ & -- & A & 47.559 & 8.048 & SL \\
\hline 12 & 2012 & Tantalum & Germany & Hanau & $\begin{array}{l}\text { Heraeus Material } \\
\text { Technology GmbH \& } \\
\text { Co. KG }\end{array}$ & $\mathrm{P}(\mathrm{F} ?)$ & $\begin{array}{l}\text { Heraeus Holding } \\
\text { GmbH }\end{array}$ & -- & A & 50.131 & 8.925 & SL \\
\hline 13 & 2012 & $\begin{array}{l}\text { Tantalum and } \\
\text { niobium }\end{array}$ & Japan & $\begin{array}{l}\text { Akita, Akita } \\
\text { Prefecture }\end{array}$ & Akita & $\mathrm{P}(\mathrm{R} ?)$ & $\begin{array}{l}\text { Japan New } \\
\text { Metals Co. Ltd. }\end{array}$ & $95^{\mathrm{e}}$ concentrate & A & 39.760 & 140.065 & GL \\
\hline 14 & 2012 & $\begin{array}{l}\text { Tantalum and } \\
\text { niobium }\end{array}$ & Japan & $\begin{array}{l}\text { Aizuwakamatsu- } \\
\text { shi, Fukushima } \\
\text { prefecture }\end{array}$ & Aizu Refinery Plant & $\mathrm{P}(\mathrm{R} ?)$ & $\begin{array}{l}\text { Global Advanced } \\
\text { Metals Pty Ltd. }\end{array}$ & -- & A & 37.460 & 139.936 & GL \\
\hline 15 & 2012 & $\begin{array}{l}\text { Tantalum and } \\
\text { niobium }\end{array}$ & Japan & Fukuoka prefecture & Miike Rare Metal & $\mathrm{P}(\mathrm{R})$ & $\begin{array}{l}\text { Mitsui Mining } \\
\text { and Smelting } \\
\text { Co. Ltd. }\end{array}$ & NA & A & 33.606 & 130.419 & GL \\
\hline 16 & 2012 & $\begin{array}{l}\text { Tantalum and } \\
\text { niobium }\end{array}$ & Japan & $\begin{array}{l}\text { Hitachi-Ohmiya, } \\
\text { Ibaraki prefecture }\end{array}$ & H.C. Starck-V Tech Ltd. & $\mathrm{P}(\mathrm{R})$ & $\begin{array}{l}\text { H.C. Starck } \\
\text { GmbH }\end{array}$ & NA & A & 36.506 & 140.615 & GL \\
\hline 17 & 2012 & Tantalum, metal & Kazakhstan & $\begin{array}{l}\text { Oskemen (also } \\
\text { known as Ust- } \\
\text { Kamenogorsk) }\end{array}$ & $\begin{array}{l}\text { Oskemen (also known as } \\
\text { Ust-Kamenogorsk) }\end{array}$ & $\mathrm{P}(\mathrm{R})$ & $\begin{array}{l}\text { Ulba } \\
\text { Metallurgical } \\
\text { Plant }\end{array}$ & NA & A & 49.982 & 82.627 & SL \\
\hline 18 & 2012 & Tantalum & Russia & $\begin{array}{l}\text { Solikamsk, Perm } \\
\text { Krai }\end{array}$ & $\begin{array}{l}\text { Solikamsk Magnesium } \\
\text { Works }\end{array}$ & $\mathrm{P}(\mathrm{R})$ & $\begin{array}{l}\text { Solikamsk } \\
\text { Magnesium } \\
\text { Works }\end{array}$ & 85 & A & 59.634 & 56.767 & GL \\
\hline
\end{tabular}


Table 3. Significant tantalum plants (fabricators and refineries).-Continued

[Locations of fabricators and refineries are shown on the map in figure 5. --, not applicable or no data; ?, uncertain; A, active; e, estimated;

F, fabricator; GL, general location; NA, not available; P, plant; R, refinery; SL, specific location. Data are from U.S. Geological Survey Minerals Yearbook 2011, vol. III (http://minerals.usgs.gov/minerals/)]

\begin{tabular}{|c|c|c|c|c|c|c|c|c|c|c|c|c|}
\hline ID & Year & $\begin{array}{l}\text { Specific mineral } \\
\text { commodity } \\
\text { and (or) } \\
\text { product }\end{array}$ & Country & Location description & Location name & $\begin{array}{l}\text { Facility } \\
\text { type }\end{array}$ & Ownership & $\begin{array}{c}\text { Annual } \\
\text { capacity } \\
\text { (metric tons) }\end{array}$ & Status & $\begin{array}{l}\text { Latitude } \\
\text { (decimal } \\
\text { degrees) }\end{array}$ & $\begin{array}{l}\text { Longitude } \\
\text { (decimal } \\
\text { degrees) }\end{array}$ & $\begin{array}{c}\text { Locational } \\
\text { accuracy }\end{array}$ \\
\hline 19 & 2012 & $\begin{array}{l}\text { Tantalum, metal } \\
\text { powder and oxides }\end{array}$ & Thailand & $\begin{array}{l}\text { Map Ta Phut, } \\
\text { Rayong Province }\end{array}$ & $\begin{array}{l}\text { H.C. Starck (Thailand) } \\
\text { Company Ltd. }\end{array}$ & $\mathrm{P}(\mathrm{R})$ & $\begin{array}{l}\text { H.C. Starck } \\
\text { (Thailand) } \\
\text { Company Ltd. } \\
\text { (H.C. Starck } \\
\text { GmbH, 94.98\%, } \\
\text { and others, } \\
5.02 \% \text { ) }\end{array}$ & $\begin{array}{l}250 \text { contained in } \\
\text { slags }\end{array}$ & A & 12.688 & 101.141 & SL \\
\hline 20 & 2012 & Tantalum & United States & $\begin{array}{l}\text { Boyertown, } \\
\text { Pennsylvania }\end{array}$ & Boyertown Plant & $\mathrm{P}(\mathrm{R})$ & $\begin{array}{l}\text { Global Advanced } \\
\text { Metals Pty Ltd. }\end{array}$ & -- & A & 40.346 & -75.612 & SL \\
\hline 21 & 2012 & Tantalum & United States & $\begin{array}{l}\text { Newton, } \\
\text { Massachusetts }\end{array}$ & H.C. Starck Inc. & $\mathrm{P}(\mathrm{R})$ & H.C. Starck Inc. & -- & A & 42.311 & -71.214 & SL \\
\hline 22 & 2012 & Tantalum & United States & $\begin{array}{l}\text { Carson City, } \\
\text { Nevada }\end{array}$ & $\begin{array}{l}\text { KEMET Blue Powder } \\
\text { Corp. }\end{array}$ & $P(F)$ & KEMET Corp. & -- & A & 39.234 & -119.657 & SL \\
\hline
\end{tabular}


Table 4. Locations of tantalum capacitor manufacturing facilities for three leading manufacturers.

[Sources: AVX Corp. (2013a), KEMET Corp. (2012b, d), and NEC TOKIN Corp. (2013)]

\begin{tabular}{ll}
\hline \multicolumn{1}{c}{ Manufacturing company } & \multicolumn{1}{c}{ Tantalum capacitor manufacturing location } \\
\hline AVX Corp. & Adogawa, Japan (formerly Nichicon Corp.) \\
& Bidderford, Maine, USA \\
& Lanskroun, Czech Republic \\
& San Salvador, El Salvador \\
& Tianjin, China (formerly Nichicon Corp.) \\
& Carson City, Nevada, USA \\
& Cuidad Victoria, Mexico \\
& Evora, Portugal \\
& Matamoros, Mexico \\
SEMET Corp. & Suzhou, China (2 facilities) \\
& Sendai City, Miyagi, Japan \\
Shiroishi City, Miyagi, Japan \\
Nyuzen-machi, Shimoniikawa District, Toyama, Japan \\
NEC TOKIN Electronics (Thailand) Co. Ltd. \\
NEC TOKIN Electronics (Xiamen) Corp. \\
NEC TOKIN Electronics (Philippines) Inc. \\
NEC TOKIN Electronics (Vietnam) Co. Ltd. \\
\hline
\end{tabular}


Table 5. Product name, description, and applications for selected tantalum capacitors produced by AVX Corp. [Source: AVX Corp. (2013b)]

\begin{tabular}{lcc}
\hline \multicolumn{1}{c}{ Tantalum capacitors } & Description & Applications \\
\hline TAZ Series & CWR09-MIL-PRF-55365/4; CWR19 MIL-PRF- & 55365/11; CWR29 MIL-PRF-55365/11; Extended \\
& Range-63V COTS-Plus Rating & $\begin{array}{l}\text { Include medical } \\
\text { devices and } \\
\text { military/aerospace. }\end{array}$ \\
TCP Series & TCP Series Low ESR Tantalum Modules & \\
TBJ Series & CWR11- MIL-PRF-55365/8 Established Reliability, \\
& COTS-Plus \& Space Level; COTS-PLUS-DSCC \\
& Dwgs 07016 \& 95158 Weibull Grade \& Space Level \\
TBM Multianode & Tantalum Ultra Low ESR COTS-Plus Weibull Grade \& \\
& Space Level \\
TBW Series & Tantalum Fused DSCC Dwg 04053 COTS-Plus Weibull & \\
& Grade \& Space Level \\
TBC Series & CWR15 MIL-PRF-55365/12 Established Reliability, \\
& COTS-Plus \& Space Level; TBC COTS-Plus \\
TWA Series & TWA Wet Electrolytic Tantalum Capacitor \\
TWM Module & AVX modular packaged 93026 qualified capacitors \\
TAJ ESCC Tantalum Capacitors & SMD Solid Tantalum Chip Capacitors \\
TAJ CECC Tantalum Capacitors & SMD Solid Tantalum Chip Capacitors \\
\hline
\end{tabular}


Table 6. Product name, product description, and applications for selected tantalum (Ta) capacitors produced by KEMET Corp.

[ABS, anti-lock braking system; DC, direct current; DSCC, Defense Supply Center Columbus; ESL, Equivalent Series Inductance; $\mathrm{HDD}$, hard disk drive; $\mathrm{kHz}$, kilohertz; $\mathrm{MnO}_{2}$, manganese oxide; PC, personal computer; SSD, solid-state drive; USB, Universal Serial Bus (USB); V, volt. Source: KEMET Corp. (2013a, b)]

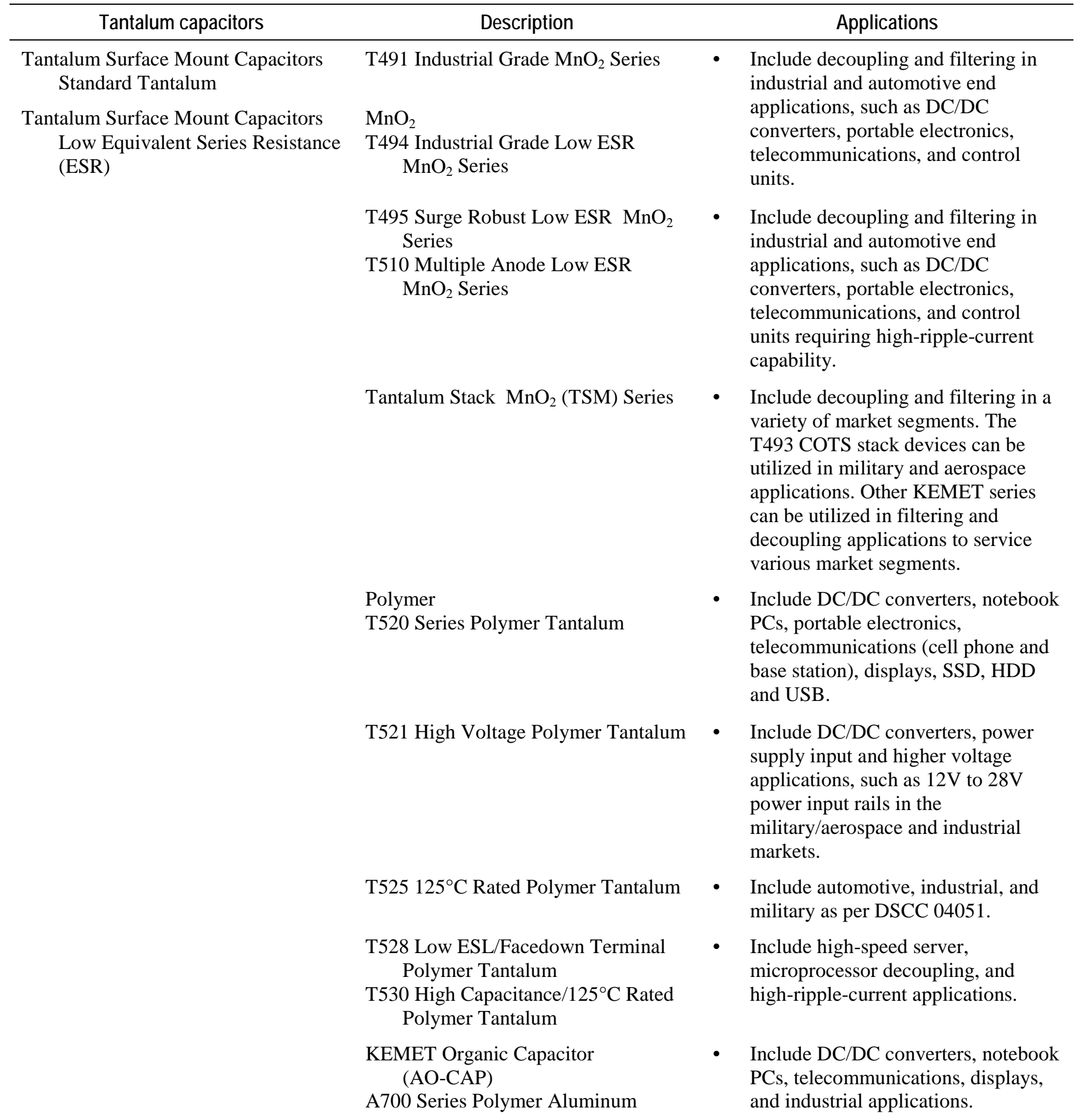


Table 6. Product name, product description, and applications for selected tantalum (Ta) capacitors produced by KEMET Corp.-Continued

[ABS, anti-lock braking system; DC, direct current; DSCC, Defense Supply Center Columbus; ESL, Equivalent Series Inductance; $\mathrm{HDD}$, hard disk drive; $\mathrm{kHz}$, kilohertz; $\mathrm{MnO}_{2}$, manganese oxide; PC, personal computer; SSD, solid-state drive; USB, Universal Serial Bus (USB); V, volt. Source: KEMET Corp. (2013a, b)]

\begin{tabular}{|c|c|c|}
\hline Tantalum capacitors & Description & Applications \\
\hline $\begin{array}{l}\text { Tantalum Surface Mount Capacitors } \\
\text { High Temperature }\end{array}$ & $\begin{array}{l}\text { T498 } 150^{\circ} \mathrm{C} \text { Rated } \mathrm{MnO}_{2} \text { Series } \\
\text { T499 } 175^{\circ} \mathrm{C} \text { Rated } \mathrm{MnO}_{2} \text { Series }\end{array}$ & $\begin{array}{l}\text { Include decoupling and filtering in } \\
\text { industrial and automotive end } \\
\text { applications, such as DC/DC } \\
\text { converters, portable electronics, } \\
\text { telecommunications, and control } \\
\text { units operating at temperatures up to } \\
175^{\circ} \mathrm{C} \text {. }\end{array}$ \\
\hline $\begin{array}{l}\text { Tantalum Surface Mount Capacitors } \\
\text { MIL-PRF (CWR Series) }\end{array}$ & $\begin{array}{l}\text { T409 Series CWR09 Style MIL-PRF- } \\
\text { 55365/4 } \\
\text { T419 Series CWR19 Style MIL-PRF- } \\
\text { 55365/11 } \\
\text { T429 Series CWR29 Style MIL-PRF- } \\
\text { 55365/8 } \\
\text { T492 CWR11 Style MIL-PRF- } \\
\text { 55365/8 }\end{array}$ & $\begin{array}{l}\text { Include decoupling and filtering in } \\
\text { military and aerospace applications } \\
\text { requiring CWR09, CWR19, CW29, } \\
\text { and CRWR11 devices (precision- } \\
\text { molded devices with compliant } \\
\text { terminations and indelible laser } \\
\text { marking). }\end{array}$ \\
\hline $\begin{array}{l}\text { Tantalum Surface Mount Capacitors } \\
\text { Fused }\end{array}$ & T496 Fused $\mathrm{MnO}_{2}$ Series & $\begin{array}{l}\text { - Include decoupling and filtering in } \\
\text { computing and telecommunications } \\
\text { end applications, such as high-end } \\
\text { servers requiring built-in fuse } \\
\text { capability. }\end{array}$ \\
\hline \multirow{3}{*}{$\begin{array}{c}\text { Tantalum Surface Mount Capacitors } \\
\text { High Reliability Commercial- } \\
\text { Off-The-Shelf (COTS) }\end{array}$} & $\begin{array}{l}\text { T493 Military/Aerospace COTS } \\
\mathrm{MnO}_{2} \text { Series }\end{array}$ & $\begin{array}{l}\text { Include decoupling and filtering in } \\
\text { military and aerospace applications }\end{array}$ \\
\hline & T497 High Grade COTS MnO $_{2}$ Series & $\begin{array}{l}\text { Include decoupling and filtering in } \\
\text { military, medical, and aerospace } \\
\text { applications. }\end{array}$ \\
\hline & $\begin{array}{l}\text { T540 Polymer COTS Series } \\
\text { T541 Polymer COTS Series }\end{array}$ & $\begin{array}{l}\text { Include decoupling and filtering in } \\
\text { military and aerospace applications } \\
\text { that require low ESR or a benign } \\
\text { failure mode. }\end{array}$ \\
\hline \multirow[t]{2}{*}{$\begin{array}{l}\text { Tantalum Surface Mount Capacitors } \\
\text { Automotive Grade }\end{array}$} & $\begin{array}{l}\text { T491 Industrial Grade } \mathrm{MnO}_{2} \text { Series } \\
\text { T494 Industrial Grade Low ESR } \\
\mathrm{MnO}_{2} \text { Series }\end{array}$ & $\begin{array}{l}\text { Include decoupling and filtering in } \\
\text { industrial and automotive end } \\
\text { applications, such as DC/DC } \\
\text { converters, portable electronics, } \\
\text { telecommunications, and control } \\
\text { units. }\end{array}$ \\
\hline & T489 Low Leakage $\mathrm{MnO}_{2}$ Series & $\begin{array}{l}\text { Include decoupling and filtering in } \\
\text { industrial and automotive high-end } \\
\text { applications. }\end{array}$ \\
\hline
\end{tabular}


Table 6. Product name, product description, and applications for selected tantalum (Ta) capacitors produced by KEMET Corp.-Continued

[ABS, anti-lock braking system; DC, direct current; DSCC, Defense Supply Center Columbus; ESL, Equivalent Series Inductance; $\mathrm{HDD}$, hard disk drive; $\mathrm{kHz}$, kilohertz; $\mathrm{MnO}_{2}$, manganese oxide; PC, personal computer; SSD, solid-state drive; USB, Universal Serial Bus (USB); V, volt. Source: KEMET Corp. (2013a, b)]

\section{Tantalum capacitors}

Tantalum Surface Mount Capacitors Automotive Grade-Continued
Description

T495 Surge Robust Low ESR $\mathrm{MnO}_{2}$ $\mathrm{MnO}_{2}$ Series

T498 $150^{\circ} \mathrm{C}$ Rated $\mathrm{MnO}_{2}$ Series T499 $175^{\circ} \mathrm{C}$ Rated $\mathrm{MnO}_{2}$ Series

T510 Multiple Anode Low ESR $\mathrm{MnO}_{2}$ Series

T525 $125^{\circ} \mathrm{C}$ Rated Polymer Tantalum

T493 Series COTS Space Grade

T496 Series Fail-Safe Fused Space Grade

T497 Series High Grade COTS Space Grade

T510 Series Multiple Anode Low ESR Space Grade
Applications

- Include decoupling and filtering in industrial and automotive end applications, such as DC/DC converters, portable electronics, telecommunications, and control units requiring high-ripple-current capability.

- Include decoupling and filtering in industrial and automotive end applications, such as DC/DC converters, portable electronics, telecommunications, and control units operating at temperatures up $175^{\circ} \mathrm{C}$,

- $\quad$ Include decoupling and filtering in industrial and automotive end applications, such as DC/DC converters, portable electronics, telecommunications, and control units requiring high-ripple-current capability.

- Include automotive, industrial, and military applications as per DSCC 04051.

- $\quad$ Include decoupling and filtering in military and aerospace applications.

- Include decoupling and filtering in computing and telecommunications end applications, such as high-end servers requiring built-in fuse capability.

- Include decoupling and filtering in military, medical, and aerospace applications.

Include decoupling and filtering in industrial and automotive end applications, such as DC/DC converters, portable electronics, telecommunications, and control units requiring-high ripple-current capability. 
Table 6. Product name, product description, and applications for selected tantalum (Ta) capacitors produced by KEMET Corp.-Continued

[ABS, anti-lock braking system; DC, direct current; DSCC, Defense Supply Center Columbus; ESL, Equivalent Series Inductance; $\mathrm{HDD}$, hard disk drive; $\mathrm{kHz}$, kilohertz; $\mathrm{MnO}_{2}$, manganese oxide; PC, personal computer; SSD, solid-state drive; USB, Universal Serial Bus (USB); V, volt. Source: KEMET Corp. (2013a, b)]

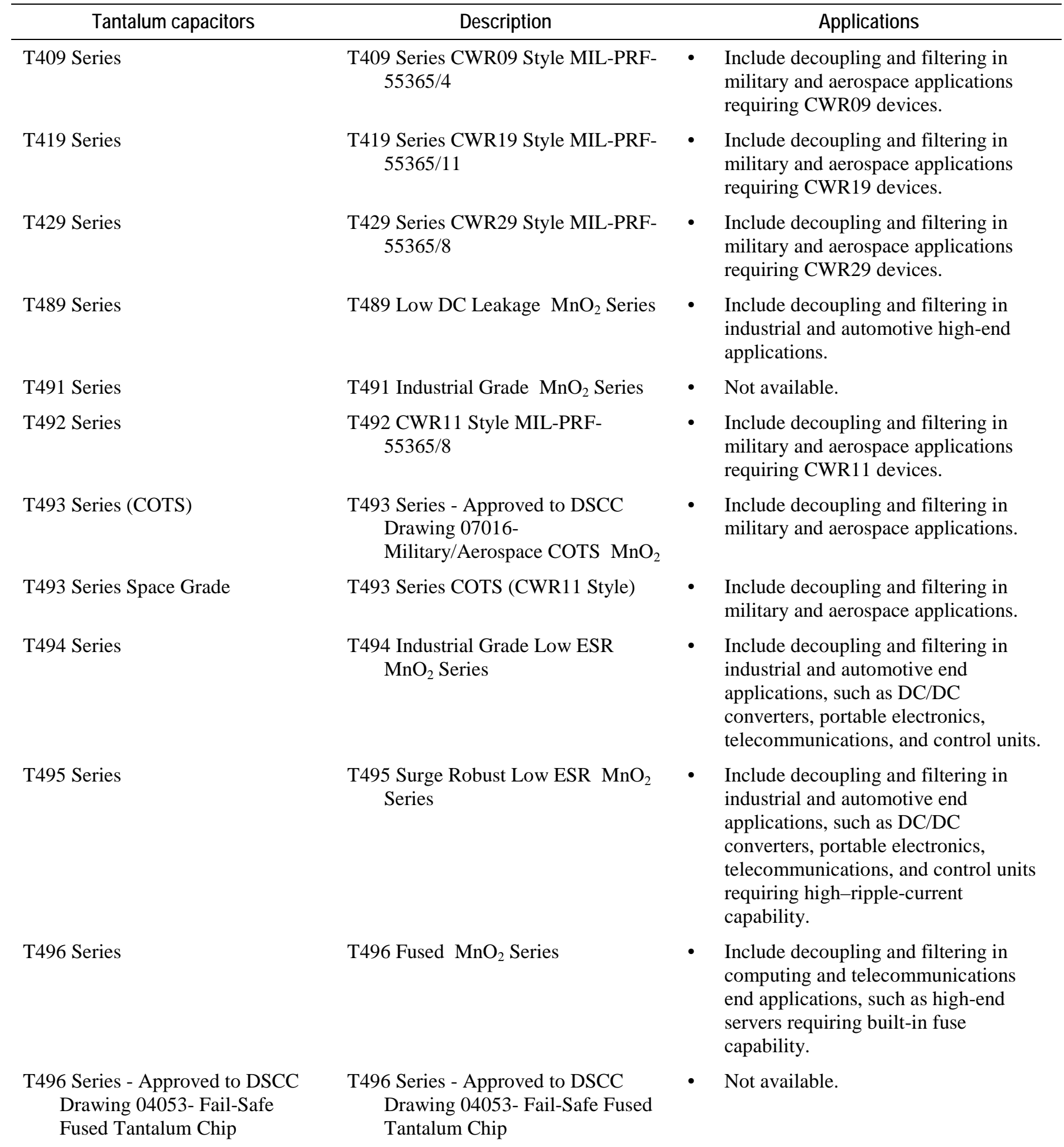


Table 6. Product name, product description, and applications for selected tantalum (Ta) capacitors produced by KEMET Corp.-Continued

[ABS, anti-lock braking system; DC, direct current; DSCC, Defense Supply Center Columbus; ESL, Equivalent Series Inductance; $\mathrm{HDD}$, hard disk drive; $\mathrm{kHz}$, kilohertz; $\mathrm{MnO}_{2}$, manganese oxide; PC, personal computer; SSD, solid-state drive; USB, Universal Serial Bus (USB); V, volt. Source: KEMET Corp. (2013a, b)]

\begin{tabular}{|c|c|c|}
\hline Tantalum capacitors & Description & Applications \\
\hline T497 Series Space Grade & $\begin{array}{l}\text { T497 Series High Grade COTS } \\
\text { (CWR09/19/29 Style) }\end{array}$ & $\begin{array}{l}\text { Include decoupling and filtering in } \\
\text { military, medical, and aerospace } \\
\text { applications. }\end{array}$ \\
\hline T510 Series & $\begin{array}{l}\text { T510 Multiple Anode Low ESR } \\
\mathrm{MnO}_{2} \text { Series }\end{array}$ & \multirow{2}{*}{$\begin{array}{l}\text { Include decoupling and filtering in } \\
\text { industrial and automotive end } \\
\text { applications, such as DC/DC } \\
\text { converters, portable electronics, } \\
\text { telecommunications, and control } \\
\text { units requiring high-ripple-current } \\
\text { capability. }\end{array}$} \\
\hline T510 Series Space Grade & $\begin{array}{l}\text { T510 Series Multiple Anode Low ESR } \\
\mathrm{MnO}_{2}\end{array}$ & \\
\hline TSM Series & $\begin{array}{l}\text { TSM Series Tantalum } \mathrm{MnO}_{2} \text { Surface } \\
\text { Mount Stack Capacitors }\end{array}$ & \multirow{2}{*}{$\begin{array}{l}\text { Include decoupling and filtering in a } \\
\text { variety of market segments. The } \\
\text { T493 COTS and } 540 \text { stack devices } \\
\text { can be utilized in military and } \\
\text { aerospace applications. Other } \\
\text { KEMET series can be utilized in } \\
\text { filtering and decoupling applications } \\
\text { to service various market segments. }\end{array}$} \\
\hline TSP Series & $\begin{array}{l}\text { TSP Series Tantalum Stack Polymer } \\
\text { Surface Mount Capacitors }\end{array}$ & \\
\hline
\end{tabular}


Table 6. Product name, product description, and applications for selected tantalum (Ta) capacitors produced by KEMET Corp.-Continued

[ABS, anti-lock braking system; DC, direct current; DSCC, Defense Supply Center Columbus; ESL, Equivalent Series Inductance; $\mathrm{HDD}$, hard disk drive; $\mathrm{kHz}$, kilohertz; $\mathrm{MnO}_{2}$, manganese oxide; PC, personal computer; SSD, solid-state drive; USB, Universal Serial Bus (USB); V, volt. Source: KEMET Corp. (2013a, b)]

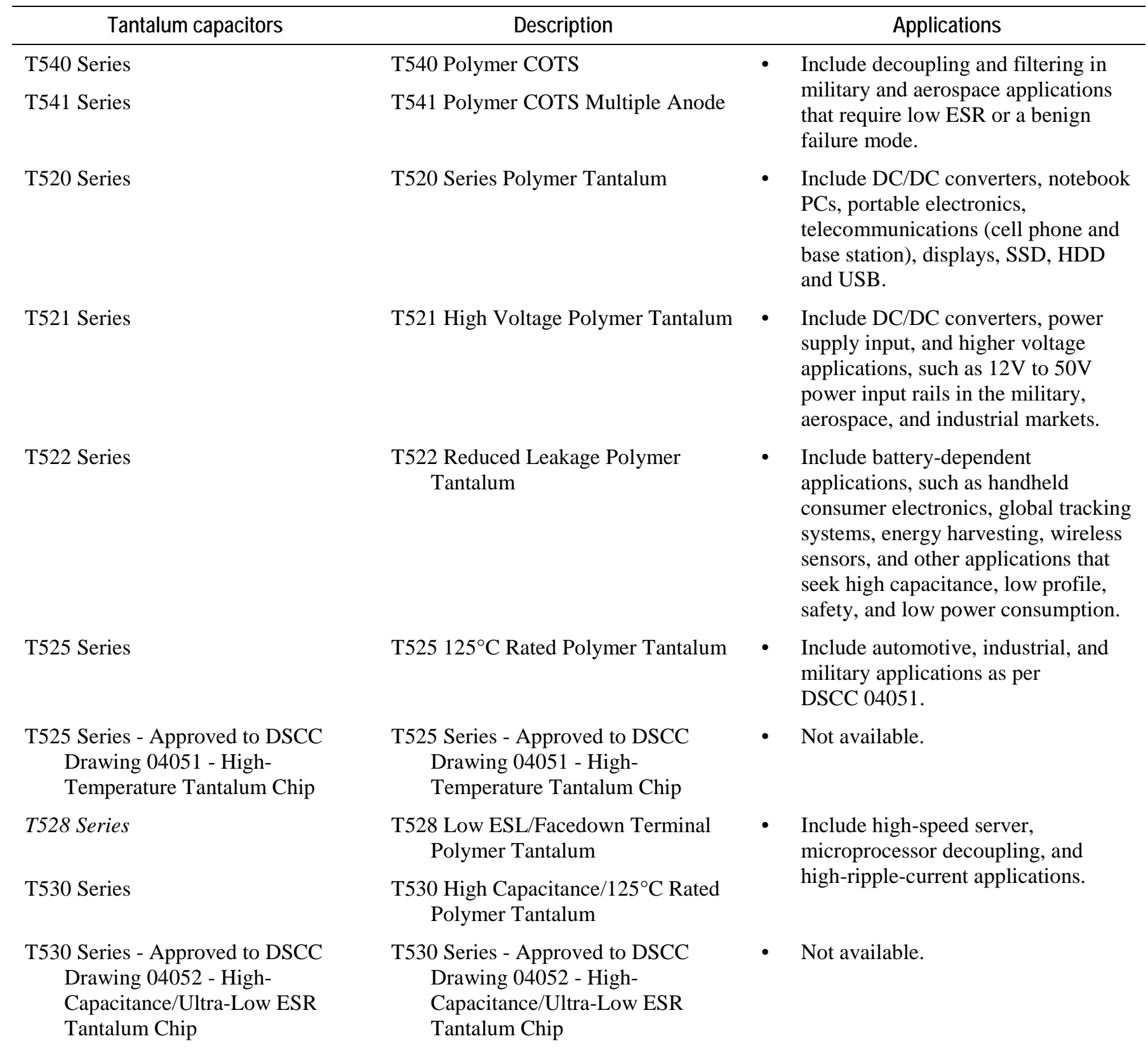


Table 6. Product name, product description, and applications for selected tantalum (Ta) capacitors produced by KEMET Corp.-Continued

[ABS, anti-lock braking system; DC, direct current; DSCC, Defense Supply Center Columbus; ESL, Equivalent Series Inductance; $\mathrm{HDD}$, hard disk drive; $\mathrm{kHz}$, kilohertz; $\mathrm{MnO}_{2}$, manganese oxide; PC, personal computer; SSD, solid-state drive; USB, Universal Serial Bus (USB); V, volt. Source: KEMET Corp. (2013a, b)]

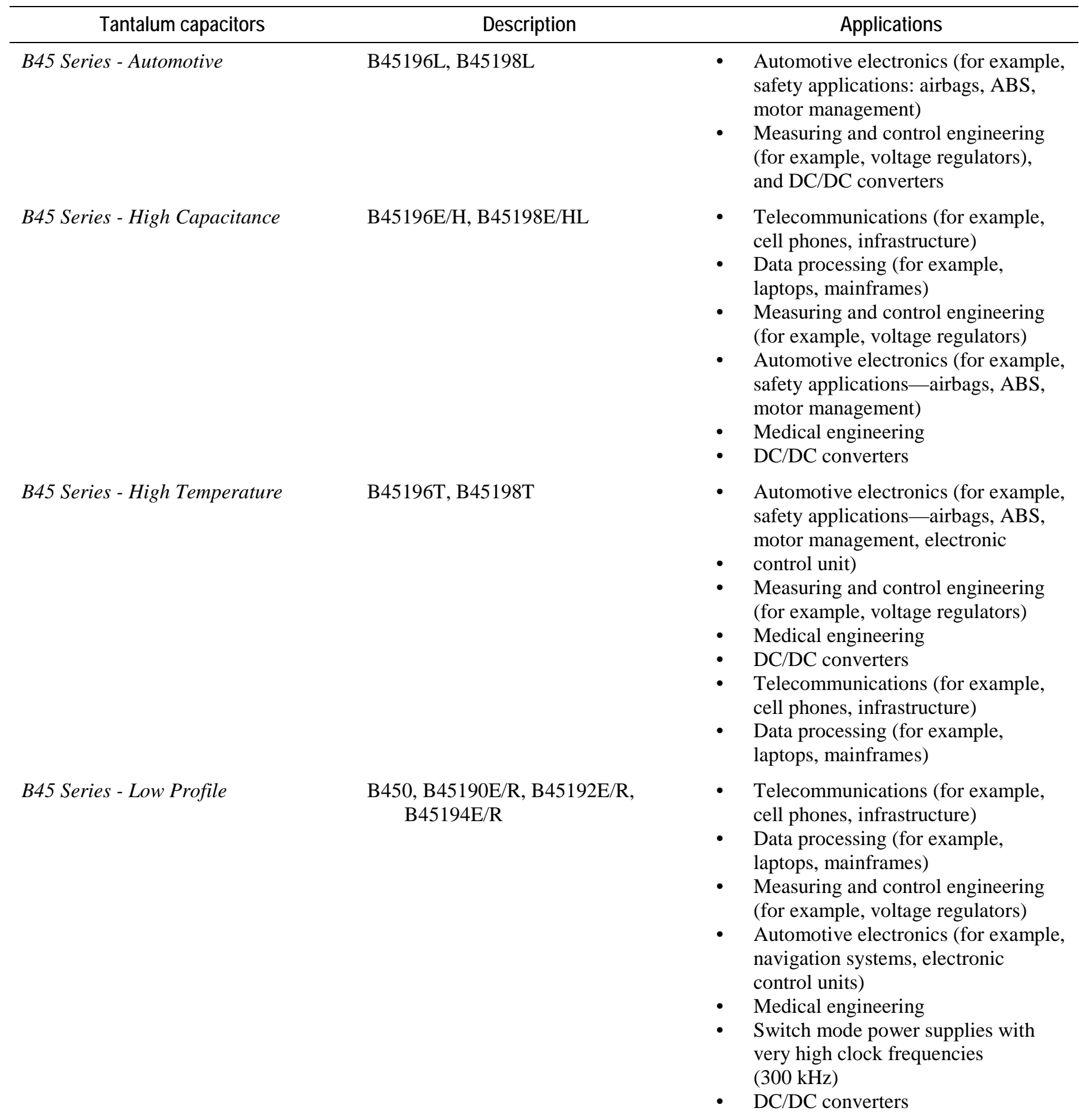


Table 6. Product name, product description, and applications for selected tantalum (Ta) capacitors produced by KEMET Corp.-Continued

[ABS, anti-lock braking system; DC, direct current; DSCC, Defense Supply Center Columbus; ESL, Equivalent Series Inductance; $\mathrm{HDD}$, hard disk drive; $\mathrm{kHz}$, kilohertz; $\mathrm{MnO}_{2}$, manganese oxide; PC, personal computer; SSD, solid-state drive; USB, Universal Serial Bus (USB); V, volt. Source: KEMET Corp. (2013a, b)]

\begin{tabular}{|c|c|c|}
\hline Tantalum capacitors & Description & Applications \\
\hline B45 Series - Multiple Anode & B45396R & $\begin{array}{l}\text { Telecommunications (for example, } \\
\text { cell phones, infrastructure) } \\
\text { Data processing (for example, } \\
\text { laptops, mainframes) } \\
\text { - Measuring and control engineering } \\
\text { (for example, voltage regulators) } \\
\text { - } \quad \text { Medical engineering } \\
\text { - } \quad \text { DC/DC converters }\end{array}$ \\
\hline B45 Series - Performance & B45196P, B45198P & 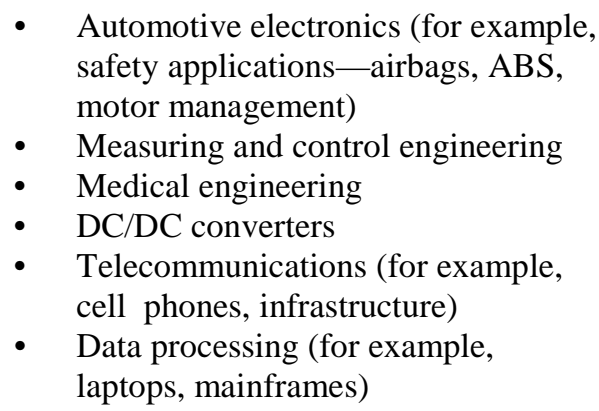 \\
\hline B45 Series - SpeedPower & B450, B451, B45197A, B45198R & $\begin{array}{l}\text { Telecommunications (for example, } \\
\text { cell phones, infrastructure) } \\
\text { Data processing (for example, } \\
\text { laptops, mainframes) } \\
\text { - Measuring and control engineering } \\
\text { (for example, voltage regulators) } \\
\text { - Automotive electronics (for example, } \\
\text { navigation systems, electronic } \\
\text { control units) } \\
\text { - Medical engineering } \\
\text { DC/DC converters }\end{array}$ \\
\hline B76 Series - Conductive Polymer & B760 & - $\quad$ Not available. \\
\hline
\end{tabular}

